\title{
21. SYNTHETIC SEISMOGRAMS, MIGRATED SEISMIC REFLECTION PROFILES, AND LITHOLOGIC CORRELATIONS FOR LEG 135 SITES IN THE LAU BASIN AND TONGA ARC ${ }^{1}$
}

\author{
T.R. Bruns, ${ }^{2}$ E.L. Geist, ${ }^{2}$ and D.L. Lavoie ${ }^{3}$
}

\begin{abstract}
At Leg 135 sites where velocity and density logs were acquired, synthetic seismograms are constructed to match seismic reflection data available for the sites. These synthetic seismograms provide a way to correlate the seismic data with the borehole lithology, and to determine what lithologic contrasts are causing the seismic reflections. Single-channel seismic reflection profiles acquired on board the JOIDES Resolution were reprocessed and migrated, and the synthetic seismogram was spliced into the profile at the location of the borehole. For Sites 840 and 841 , synthetics were also constructed to match migrated multichannel seismic reflection profiles obtained by the U.S. Geological Survey research vessel S.P. Lee. The match between synthetic and real data is variable; for lines crossing Sites $834,835,838,839$, and 840 , some excellent correlations can be made; for Site 841, the match of synthetic to real data is poor. Observed reflections are associated with lithologic unit boundaries; with coarse beds such as conglomerate, vitric gravel, and vitric sand; with basalts either within the basement or, as at Site 841, within the sedimentary section; and with sedimentary interbeds in basement basalts. Poor correlations between synthetic and real data are caused by rapid lateral changes in lithology at Site 840 , and probably by a combination of rapid lithologic changes and faulting at Site 841 .
\end{abstract}

\section{INTRODUCTION}

Seismic reflection data available over Ocean Drilling Program (ODP) Leg 135 sites (Fig. 1) include three multichannel profiles collected before the cruise (S.P. Lee Cruise L5-82-SP, lines 8 and 14 over Site 840 and line 12 over Site 841 ; Scholl and Vallier, 1985), and single-channel records collected on board the JOIDES Resolution during the cruise (Table 1). A segment of single-channel data across each site was reprocessed and migrated for this report. Geophysical well logs were also collected during Leg 135 at six sites (Table 1); for each of these sites, the sonic and density logs allow the computation of a vertical incidence synthetic seismogram that can be compared with the seismic reflection data.

In this report, we show for each site with well logs the synthetic seismogram and the corresponding migrated seismic reflection data. The seismogram is plotted together with the velocity data, the calculated reflectivity coefficient, and a simplified lithologic column. We also show the migrated multichannel or single-channel seismic reflection profiles with the computed synthetic seismogram spliced into the site location. For two sites for which no logs were acquired, we show the migrated seismic reflection data and corresponding lithologic column plotted in time. Finally, we present a brief discussion for each site of how the synthetic seismogram correlates to the real reflection data and to the drilled lithology.

\section{GEOPHYSICAL DATA COLLECTED OVER DRILL SITES}

During Leg 135, geophysical data collected over the drill sites included 12 - and $3.5-\mathrm{kHz}$ bathymetric profiles, single-channel seismic reflection records, and magnetic data. The single-channel data were collected using two 80 -in. ${ }^{3}$ air guns that operated at an air pressure of about 2000 psi. The guns were towed $25 \mathrm{~m}$ behind the ship at a water depth of about $10 \mathrm{~m}$. Data were recorded through a

\footnotetext{
${ }^{1}$ Hawkins, J., Parson, L., Allan, J., et al., 1994. Proc. ODP, Sci. Results, 135: College Station, TX (Ocean Drilling Program).

${ }^{2}$ Branch of Pacific Marine Geology, U.S. Geological Survey, M.S. 999. 345 Middlefield Road, Menlo Park, CA 94025 , U.S.A

${ }^{3}$ Naval Research Laboratory-Detachment, Ocean Science Directorate, Seafloor, Geosciences Division, Stennis Space Center, MS 39529-5004, U.S.A.
}

Teledyne single-channel streamer with a 100 -m-long active section containing 60 hydrophones, which was towed $200-300 \mathrm{~m}$ behind the ship. The time interval between shots ranged from 10 to $14 \mathrm{~s}$ and the shot interval between 29 and $47 \mathrm{~m}$, because the survey speed varied from 4.8 to $6.6 \mathrm{kt}$ (Table 1). The seismic reflection data were recorded at a 1-ms sample rate on a Masscomp 561-based acquisition system using the HIGHRES software. Data were filtered to between 5 and $250 \mathrm{~Hz}$ and recorded on tape in SEG-Y format.

Navigation was based mainly on the global positioning system (GPS), with transit-satellite data used during periods when GPS was not available. All calculated positions, as well as course and speed data, were recorded on the Masscomp computer.

Multichannel seismic reflection data were collected on the U.S. Geological Survey research vessel S.P. Lee using a Globe Universal Sciences Model 4200 seismic recording system, a Seismic Engineering towed acoustic array or streamer, and a seismic source of five Bolt air guns with a total volume of $19.86 \mathrm{~L}^{3}$ (Mann, 1985). The acoustic array consisted of 24 active sections, each $100 \mathrm{~m}$ long and containing 60 hydrophones. The shot interval was $50 \mathrm{~m}$, resulting in 24 -fold data. Data were recorded at a 2-ms sample rate. Navigation was based on transit satellite fixes augmented by dead reckoning positions (Steele et al., 1985).

Digital tapes of both the seismic reflection data and the navigation data are available from the Data Librarian at ODP headquarters at College Station, Texas; the Site Survey Data Bank at Lamont-Doherty Geological Observatory, Columbia University, Palisades, New York; and the National Geophysical Data Center (NGDC) at Boulder, Colorado. Tapes for the multichannel seismic reflection data shown here are also available from NGDC. Digital tapes of the reprocessed data are available at the requesters expense through $\mathrm{E}$. Geist or T. Bruns at the U.S. Geological Survey in Menlo Park, California.

\section{POST-CRUISE PROCESSING OF SEISMIC REFLECTION DATA}

Single-channel seismic reflection data were reprocessed at the U.S. Geological Survey Branch of Pacific Marine Geology in Menlo Park, California. A typical processing scheme included editing noisy traces, resampling to $2 \mathrm{~ms}$, trace balance, predictive deconvolution (with a 12 -ms gap, a 100 -ms operator, and a 1000 -ms design window subseafloor), bandpass filtering (15-20-70-80 Hz to match the bandwidth of the records), finite-difference migration, and water bottom mute. 


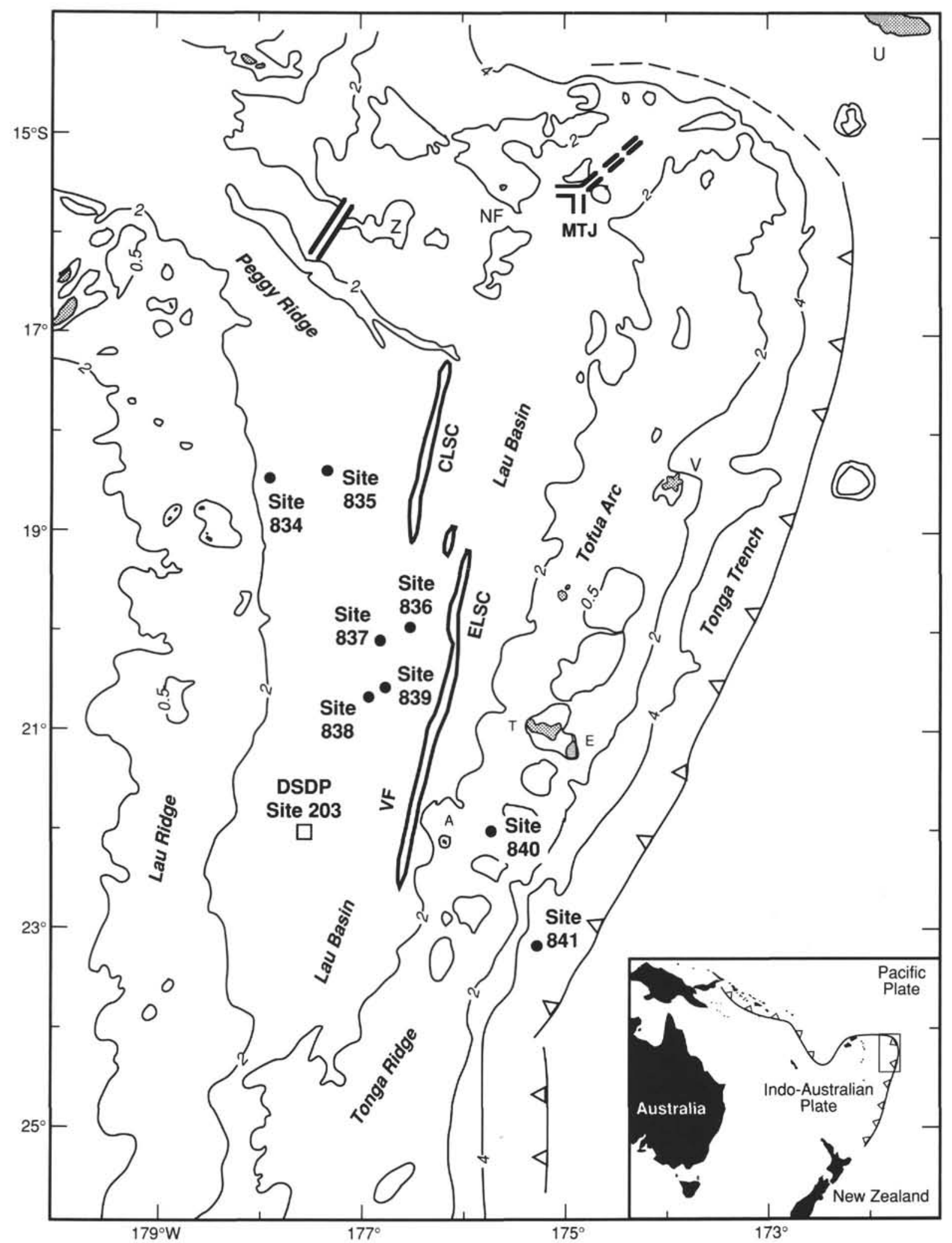

Figure 1. Bathymetric chart of the Lau Basin area and location of Sites 834-841 drilled during Leg 135. The figure also shows the regional setting and the major geologic features of the Tonga Trench and Lau Basin system. Islands shown are Tongatapu (T), 'Eua (E), Vava'u (V), Niuafo' ou (NF), 'Ata (A), and Upolu (U), Western Samoa. Locations of the Central Lau (CLSC) and Eastern Lau (ELSC) spreading centers, Valu Fa Ridge (VF), and Mangatolu Triple Junction (MTJ) are after Parson, Hawkins, Allan, et al. (1992) and references contained therein. $Z=$ Zephyr Shoal. The location of DSDP Site 203 is shown as an open square. Contour intervals in kilometers. 
Multichannel seismic reflection data were processed and migrated for inclusion in Scholl and Vallier (1985) and in preparation for Leg 135. Processing of these data is described by Mann (1985). Multichannel lines 8 and 14 (Site 840 ) were also reprocessed by Digicon in 1988 for the Committee for Co-ordination of Joint Prospecting for mineral resources in South Pacific offshore areas (CCOP/SOPAC). These reprocessed lines are available through CCOP/SOPAC, c/o Mineral Resources Department, Suva, Fiji. The Digicon reprocessed lines are shown in this report.

\section{COMPUTATION OF SYNTHETIC SEISMOGRAMS}

Sonic velocity and density logs were acquired at Sites 834-835 and $838-841$. To create the synthetic seismogram, the sonic and density logs were first edited to remove obviously erroneous values. Sonic logs are required to compute a synthetic, but where no density information was available (mainly when sonic and density logs reached different depths in the hole), Lindseth's formula (density = [velocity -3460 $\mathrm{ft} / \mathrm{s}] / 0.308 \mathrm{x}$ velocity) was used to convert the sonic velocity to a density value (Lindseth, 1979). Logs were then converted from depth to time by using a conversion derived from the velocity log. Reflection coefficients were computed from the acoustic impedance, accounting for vertical-incidence transmission and reflection losses through the section. The synthetic seismogram was then created by convolving the reflection coefficients with a $45-\mathrm{Hz}$ minimum phase wavelet for the single-channel seismic reflection data and a $25-\mathrm{Hz}$ minimum phase wavelet for the multichannel data. The dominant frequency of the minimum phase wavelet was chosen to match the observed dominant frequency of the single-channel or multichannel seismic reflection data.

\section{COMPARISONS OF SEISMIC REFLECTION RECORDS, DOWNHOLE LITHOLOGY, AND SYNTHETIC SEISMOGRAMS}

In this section, we show for each site (1) the computed synthetic seismogram plotted alongside the corresponding velocity log, the acoustic impedance log and lithologic column (annotated in both time and depth); (2) the synthetic seismogram spliced into a 40-shotpoint segment of the corresponding seismic reflection profile to show details of the synthetic to real data correlation around the borehole; and (3) the synthetic seismogram spliced into a long section of the seismic profile (the segment of the line is given in Table 1) to show the relation of the synthetic to the regional seismic reflection profile. Dissimilarities between the synthetic seismograms and the seismic reflection data arise because of erroneous values in the logging data, because of the differing frequency contents of the synthetic and the reflection data, and because the Fresnel zone of the reflection data takes in a substantially larger area than just the borehole and therefore includes reflections generated by rocks and structures surrounding the borehole. In the synthetic seismograms, the computed reflections represent only the information sampled in the borehole. The simplified lithologic column and any lithologic descriptions presented below are from the appropriate site chapter in the Initial Reports volume for Leg 135 (Parson, Hawkins, Allan, et al., 1992). The lithologic column is plotted in two-way traveltime in seconds to match the seconds scale of the seismogram. Depths are annotated along with time to provide a timeto-depth correlation, with the notable effect that the $50-\mathrm{m}$ plotting interval is variable in width because of velocity-conversion effects.

\section{Site 834}

Site 834 is located in the northwestern part of the Lau Basin about $100 \mathrm{~km}$ east of the Lau Ridge in $2688 \mathrm{~m}$ of water (Figs. 1-2). In Hole $834 \mathrm{~B}$, total sediment thickness overlying basalt was $112.5 \mathrm{~m}$; basalt was cored to a total depth of 435.3 mbsf. Logging data were acquired only to about 412 mbsf.

JOIDES Resolution seismic reflection line 1 (shotpoints 56405780) crosses the site at shotpoint 5720 (Fig. 2 and Table 1). The synthetic seismogram for Hole 834B (Fig. 3) shows reflections from the middle to lower part of Unit II (late Pliocene nannofossil ooze with volcanic sand and silt) and the top of Unit III (Pliocene thick volcanic sand and volcanic silt with nannofossil clayey mixed sediment), and from sediment interbeds within the basalt at about 136 and $162 \mathrm{mbsf}$. No strong reflections are generated at the top of the basalt at 112.5 mbsf or within the basalt below $162 \mathrm{mbsf}$.

The strongest reflection is from the lower part of Unit II, centered at about $70 \mathrm{~ms}$. Examination of the sonic log shows that the strong reflection arises from a change in the velocity from about 1500 to 3800 $\mathrm{m} / \mathrm{s}$ and back to $1500 \mathrm{~m} / \mathrm{s}$ over the interval from 60 to $75 \mathrm{mbsf}$. In Hole $834 \mathrm{~A}$, with full recovery, no sediments were recovered with this velocity value. Hole $834 \mathrm{~B}$ did not recover core from the high-velocity section. We wonder if this high velocity may reveal invalid logging

Table 1. List of sites, line numbers, and segments of seismic reflection data that cross each site.

\begin{tabular}{|c|c|c|c|c|c|c|c|c|}
\hline Site & $\begin{array}{l}\text { Line } \\
\text { number }\end{array}$ & $\begin{array}{l}\text { Line } \\
\text { segment } \\
\text { (time) }\end{array}$ & $\begin{array}{l}\text { Line } \\
\text { segment } \\
\text { (sp) }\end{array}$ & $\begin{array}{l}\text { Site } \\
\text { location } \\
\text { (sp) }\end{array}$ & $\begin{array}{l}\text { Shot } \\
\text { rate } \\
(\mathrm{s})\end{array}$ & $\begin{array}{l}\text { Ship } \\
\text { speed } \\
(\mathrm{kt})\end{array}$ & $\begin{array}{c}\text { Shot } \\
\text { interval } \\
\text { (m) }\end{array}$ & $\begin{array}{l}\text { Synthetic } \\
\text { seismogram } \\
\text { (from logs) }\end{array}$ \\
\hline \multicolumn{9}{|c|}{ Single-channel seismic reflection profiles (JOIDES Resolution): } \\
\hline 834 & 1 & $0717-0749$ & $5640-5780$ & 5720 & 12 & 4.8 & 30 & Yes \\
\hline 835 & 2 & $0354-0442$ & $1260-1500$ & 1369 & 12 & 5.6 & 35 & Yes \\
\hline 836 & 3 & $0302-0330$ & $7740-7910$ & 7814 & 10 & 5.6 & 29 & No \\
\hline 837 & 4 & $1955-2021$ & $1400-1560$ & 1487 & 10 & 6.4 & 33 & No \\
\hline 838 & 5 & $1725-1753$ & $5880-6050$ & 5960 & 10 & 6.0 & 31 & Yes \\
\hline 839 & 6 & 0819-0858 & $630-867$ & 775 & 10 & 6.2 & 32 & Yes \\
\hline 841 & 8 & $0911-0956$ & $220-420^{\circ}$ & 267 & 14 & 6.6 & 47 & Yes \\
\hline 841 & 8 & $1136-1218$ & $840-1020$ & 931 & 14 & 6.6 & 47 & Yes \\
\hline \multicolumn{9}{|c|}{ Multichannel seismic reflection profiles (S.P. Lee): } \\
\hline 840 & 8 & - & $1100-1297$ & 1200 & - & - & 50 & Yes \\
\hline 840 & 14 & - & $1890-2070$ & 1970 & - & - & 50 & Yes \\
\hline 841 & 12 & - & $1700-1880$ & 1758 & - & - & 50 & Yes \\
\hline
\end{tabular}

Notes: Single-channel data were acquired from the JOIDES Resolution; multichannel data from the U.S Geological Survey research vessel S.P. Lee. Single-channel data were reprocessed for this report; all data are migrated. Also shown are the site locations at which either a synthetic seismogram or a lithologic column is spliced into the line segment, shot rates, ship speeds, and shot intervals for each line, and a statement of whether a synthetic seismogram was calculated (i.e., whether velocity and density logs were acquired in the hole). 


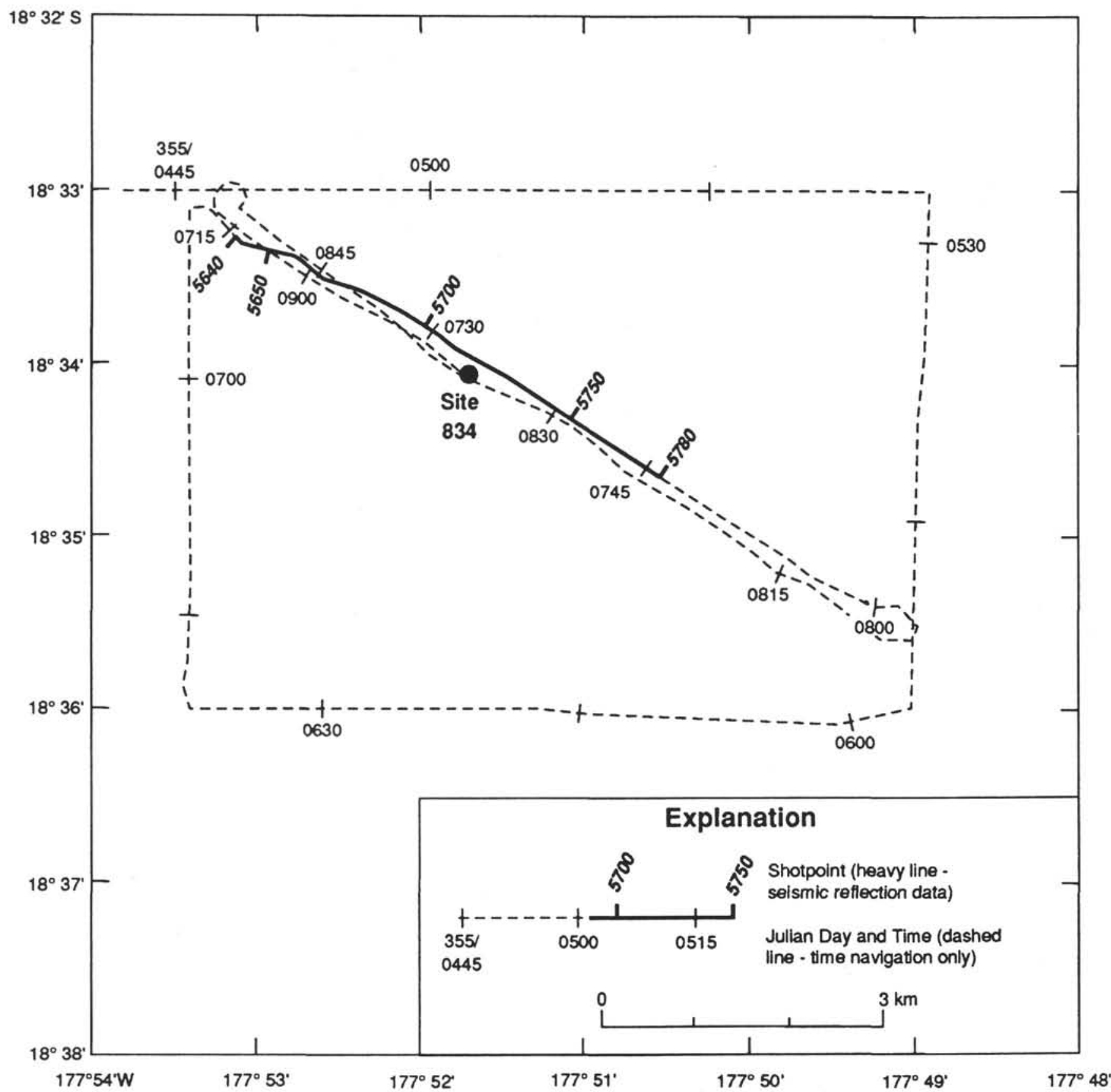

Figure 2. Location of JOIDES Resolution seismic line 1 across Site 834.

data. However, the derived reflection on the synthetic seismogram fits very well with a strong reflection at $3.70-3.73 \mathrm{~s}$ on line 1 (Figs. 4-5). Thus, despite not having sampled a lithology corresponding to the high velocity, we chose not to edit out this high-velocity data.

The lack of a strong reflection corresponding to the top of the basalt at 112.5 mbsf is surprising, as a marked increase in velocity and density occurs there on the sonic and density logs. The corresponding reflection event is probably obscured by constructive interference with overlying events.

Positive reflections on the synthetic centered at about 145 and 165 ms (Fig. 3) correlate well with sediment interbeds at 136 and 162 mbsf. Below about $180 \mathrm{~ms}$, only minor reflections are generated from velocity or density changes in basalt Units 6-12. Although some sediment was recovered within the basalts, no sediment interbed was thick enough to generate a reflection event.

Although some aspects of the synthetic are puzzling, mainly the strong Unit II reflection and the reflection-free zone at the Unit III/Unit 2 sediment/basalt contact, the synthetic matches well with the seismic reflection data (Figs. 4-5). The first event on the synthetic corresponds to a major change in reflection character on the reflection data, and the synthetic event generated at the 136-mbsf sediment interbed similarly matches a moderately continuous event on the data for line 1 . On line 1, reflections from below the basalt have a roughly layered appearance throughout the seismic reflection profile. Based on the synthetic seismogram, we postulate that these events may correspond to sediment interbeds within the basalt. 


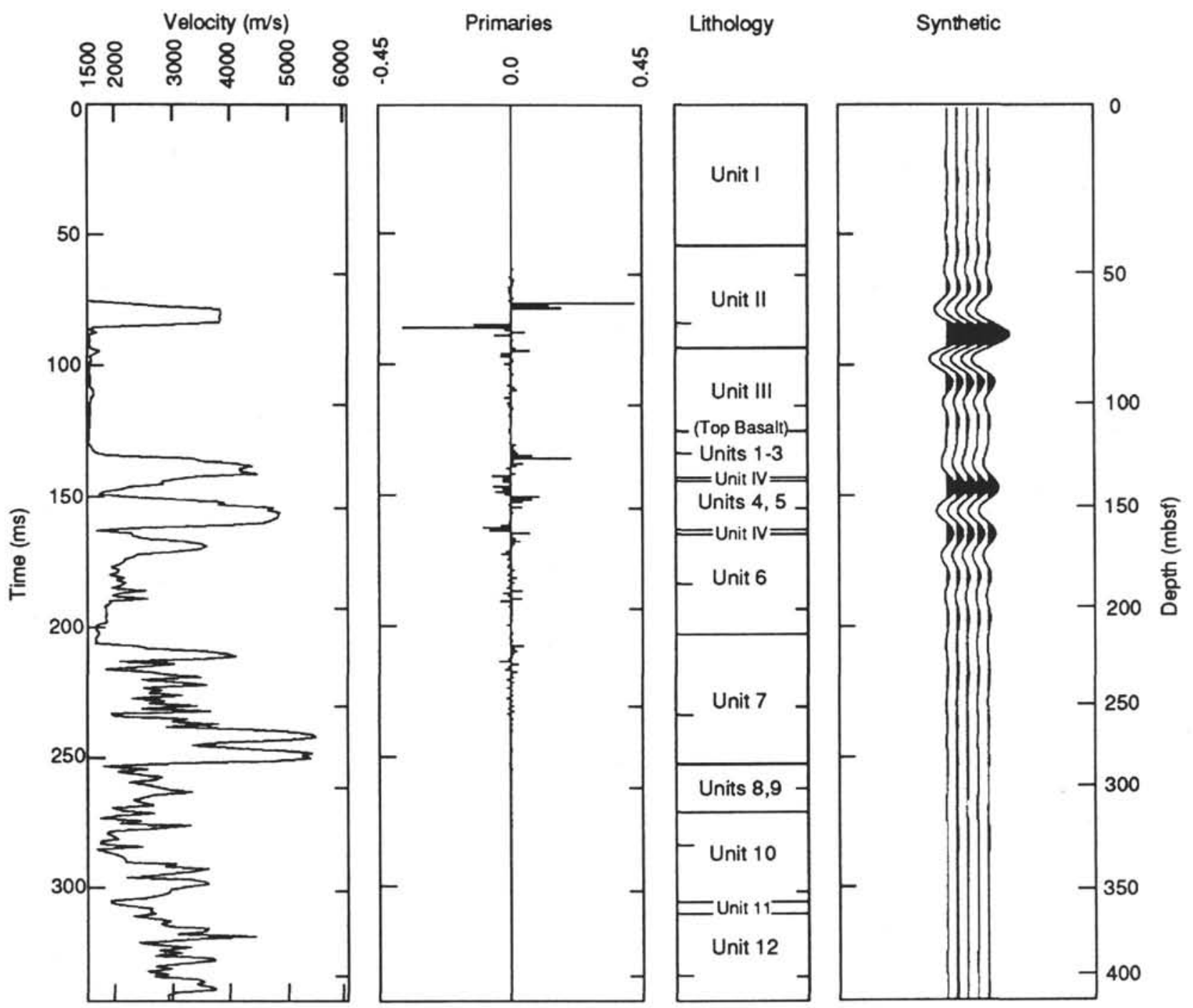

Figure 3. Plot of sonic velocity from logging data $(\mathrm{m} / \mathrm{s})$, plot of calculated reflection coefficients, simplified lithologic column, and synthetic seismogram for Hole 834B. Lithologic column is from Parson, Hawkins, Allan, et al. (1992, pp. 85-180). Two-way traveltime in ms annotated on left side of each column, and depth in mbsf annotated on right side.

\section{Site 835}

Site 835 is located in $2906 \mathrm{~m}$ of water in the west central Lau Basin, about $200 \mathrm{~km}$ east of the foot of the remnant arc of the Lau Ridge, and about $80 \mathrm{~km}$ west of the propagating ridge of the Central Lau Spreading Center (CLSC; Figs. 1 and 6). At this site, $155 \mathrm{~m}$ of Pliocene and Pleistocene sedimentary rocks were cored, including clayey nannofossil oozes, mud-clast conglomerates, turbiditic foraminiferal sands and oozes, and clayey nannofossil mixed sediments. Also cored were $28 \mathrm{~m}$ of basalt underlying the sedimentary rocks. Logs were acquired to a depth of about $170 \mathrm{mbsf}$, with velocities obtained to a depth of about $160 \mathrm{mbsf}$.

JOIDES Resolution seismic reflection line 2 (shotpoints 12601500) crosses the site at shotpoint 1369 (Table 1 and Fig. 6). Major reflections arise from near the base of Unit I at 145-165 ms (about $109-122$ mbsf), from within Unit II at $180-190$ ms (about $134-140$ mbsf), and from the top of the basalt basement Unit 1 at $200 \mathrm{~ms}$ (155 mbsf; Fig. 7). Between 70 and $150 \mathrm{~ms}$, high-velocity sedimentary interbeds within Unit I cause minor reflections. The $P$-wave logger measurements on the cores show increased velocities within these intervals, thus corroborating the sonic log data (Parson, Hawkins, Allan, et al., 1992, pp. 181-245).
The synthetic seismogram reflections match the real reflections on seismic line 2 moderately well (Figs. 8-9). The sedimentary section lies between 0 and $150 \mathrm{~ms}(0-145 \mathrm{mbsf})$ on the reflection data, and seismic reflections indicate that the sediments are poorly layered. The first major reflection at $145-165 \mathrm{~ms}$ on the synthetic seismogram correlates with the first strong reflection on the seismic record at about $4.05 \mathrm{~s}$, and also correlates with a mud-clast conglomerate sampled in the borehole at the base of Unit I (122-128 mbsf). A reflection centered at about $180 \mathrm{~ms}$ ( $140 \mathrm{mbsf}$ ) arises from rocks within Unit II. No obvious lithologic unit or change is seen in the sampled sediments to account for this reflection. However, high velocities were recorded on $P$-wave logger data, consistent with the velocity log results. Strong reflections below about $220 \mathrm{~ms}$ correspond to the basalt.

\section{Site 836}

Site 836 is located in $2455 \mathrm{~m}$ of water in the western Lau Basin about $220 \mathrm{~km}$ east of the Lau Ridge and about $48 \mathrm{~km}$ west of the Eastern Lau Spreading Center (ELSC; Figs. 1 and 10). The site cored $21 \mathrm{~m}$ of Pleistocene clayey nannofossil ooze with interbedded volcanic sands and silts, overlying about $37 \mathrm{~m}$ of basalt breccia and basalt. No logs were run at Site 836. 


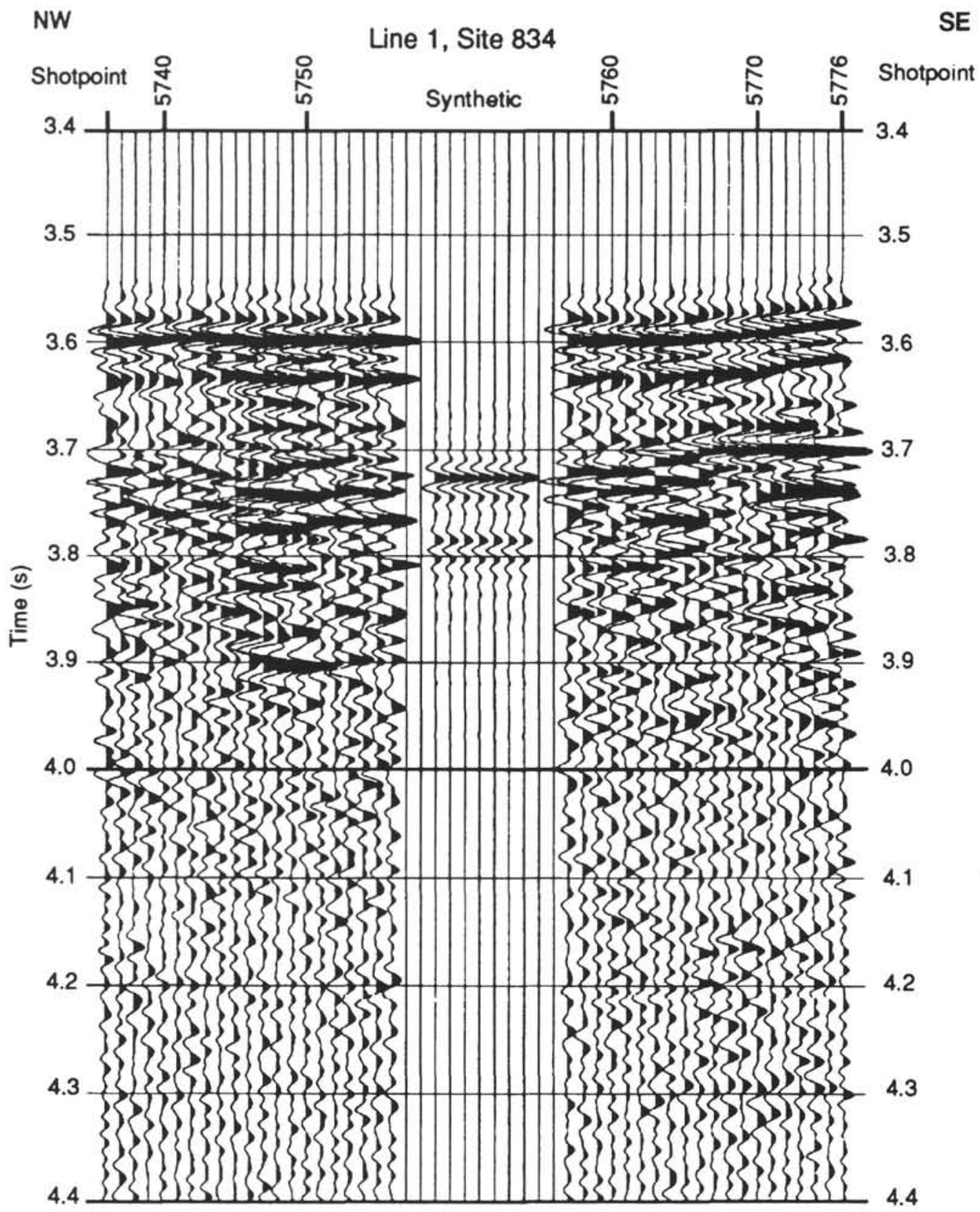

Figure 4. Synthetic seismogram for Hole 834B spliced into a 40-shotpoint segment of migrated JOIDES Resolution seismic line 1. Line location shown in Figure 2.

JOIDES Resolution seismic reflection line 3 (shotpoints 7740 7910) crosses the site at shotpoint 7814 (Fig. 10 and Table 1). We show in Figure 11 the reprocessed and migrated seismic line with a lithologic column spliced in at shotpoint 7814 (Fig. 11). The conversion of depth to time is made using velocities measured on board, where $P$-wave logger velocities in the sediments average $1527 \mathrm{~m} / \mathrm{s}$, and 11 measured basalt samples have an average velocity of $4442 \mathrm{~m} / \mathrm{s}$ (Parson, Hawkins, Allan, et al., 1992, pp. 247-287). The entire cored section lies in the upper $45 \mathrm{~ms}$ of reflections on the seismic record.

\section{Site 837}

Site 837 is located in $2752 \mathrm{~m}$ of water in the central Lau Basin about $160 \mathrm{~km}$ east of the Lau Ridge remnant arc and about $69 \mathrm{~km}$ west of the axial rift zone of the ELSC (Figs. 1 and 12). An 84-m-thick Pliocene and Pleistocene sedimentary sequence and about $15.6 \mathrm{~m}$ of basalt were cored to a total depth of $99.6 \mathrm{mbsf}$. The sediment thickness was variable: in Hole $837 \mathrm{~A}, 84 \mathrm{~m}$ of sediment were cored, whereas in Hole $837 \mathrm{~B}, 20 \mathrm{~m}$ away, only $72 \mathrm{~m}$ of sediment were cored. The region in which the site was located could be faulted or have a highly irregular basement surface.

JOIDES Resolution seismic reflection line 4 (shotpoints 1400-1560) crosses the site at shotpoint 1487 (Figs. 12-13 and Table 1). We show here the reprocessed and migrated seismic line with a lithologic column spliced in at shotpoint 1487 . The conversion of depth to time is made using velocities measured on board, where $P$-wave logger velocities in the sediments averaged $1504 \mathrm{~m} / \mathrm{s}$ and ranged between about 1500 and $1600 \mathrm{~m} / \mathrm{s}$, and two basalt samples had an average velocity of $3900 \mathrm{~m} / \mathrm{s}$ (Parson, Hawkins, Allan, et al., 1992, pp. 289-335). The entire cored section lies in the upper $120 \mathrm{~ms}$ of the reflections on the seismic record (from about 3.68 to $3.80 \mathrm{~s}$ ). On the migrated seismic line across the site, only a weak basement reflection is observed at about $3.79 \mathrm{~s}$. 
NW

JOIDES Resolution Line 1, Site 834

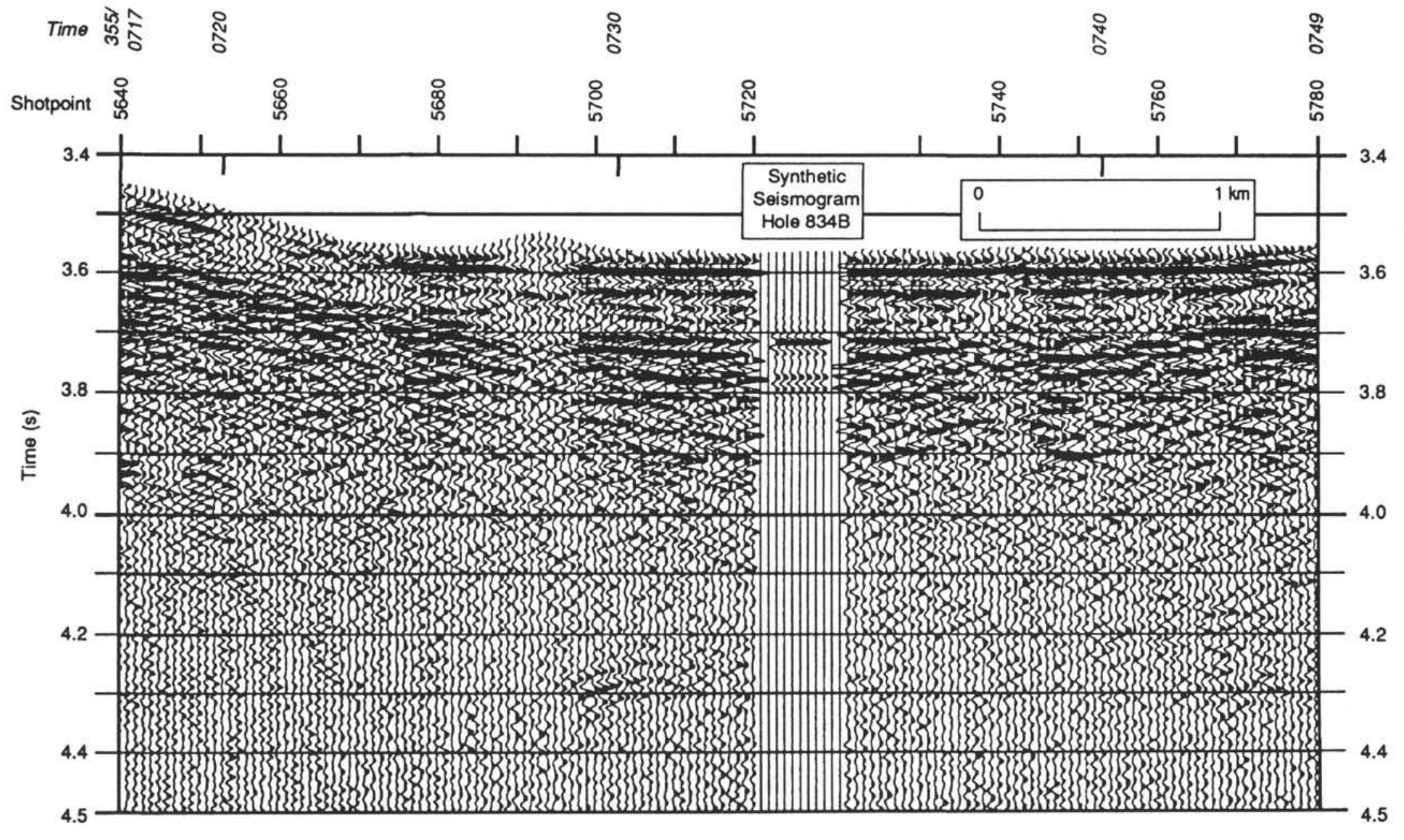

Figure 5. Synthetic seismogram for Hole 834B spliced into migrated JOIDES Resolution seismic line 1, shotpoints 5640-5780. Line location shown in Figure 2. 


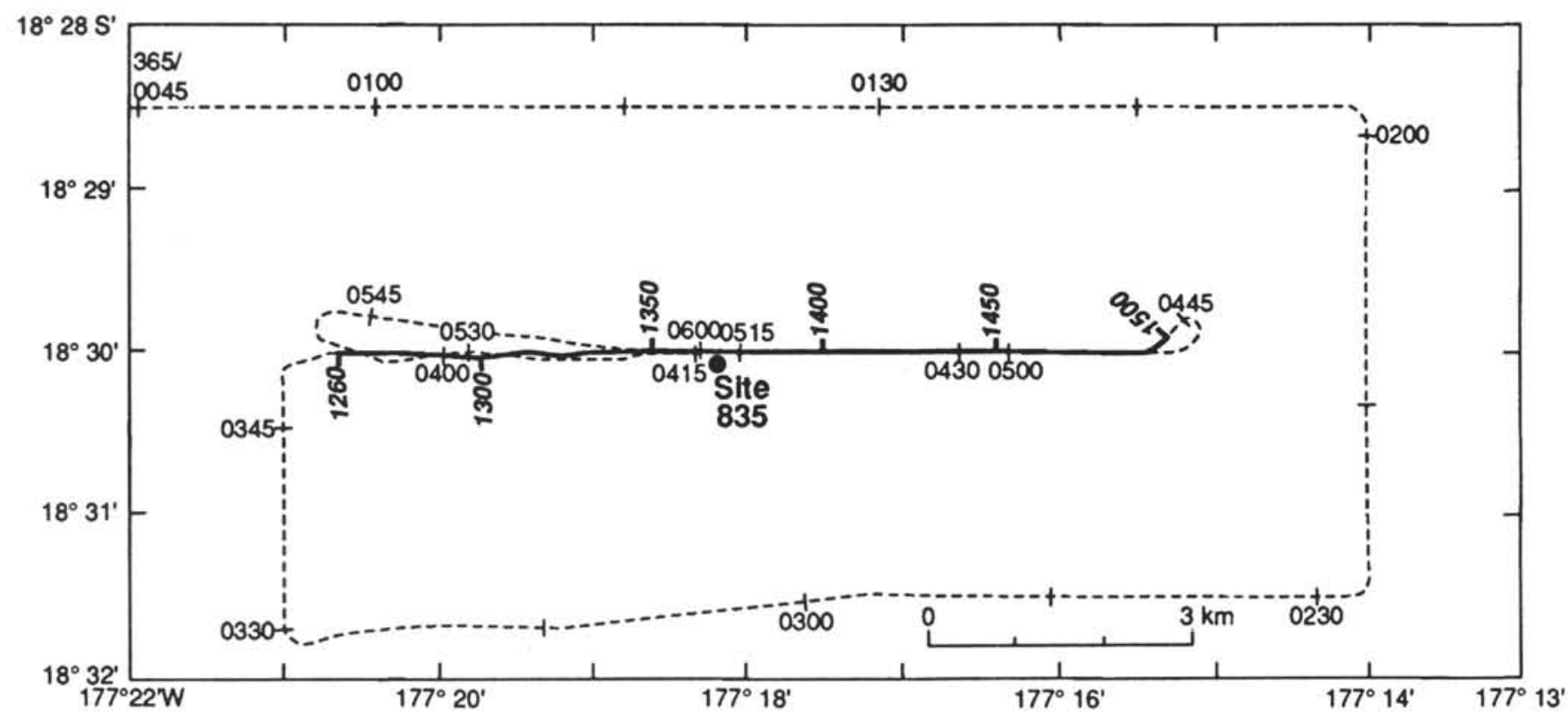

Figure 6. Location map of JOIDES Resolution seismic reflection line 2 across Site 835.

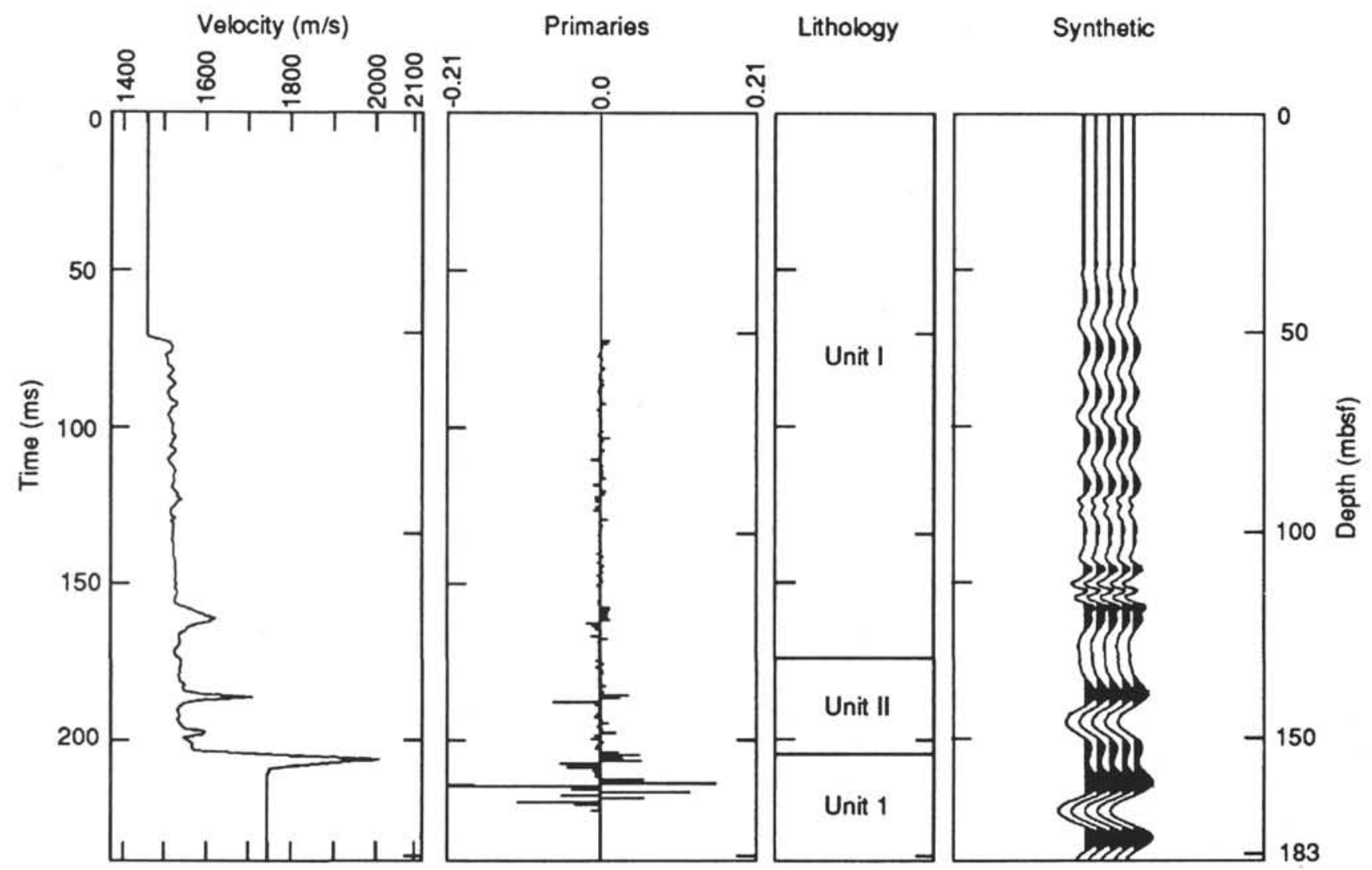

Figure 7. Plot of sonic velocity from logging data $(\mathrm{m} / \mathrm{s})$, plot of calculated reflection coefficients, simplified lithologic column, and synthetic seismogram for Hole 835B. Lithologic column is from Parson, Hawkins, Allan, et al. (1992, pp. 181-245). Two-way traveltime in ms annotated on left side of each column, and depth in mbsf annotated on right side. 
W

Line 2, Site 835

$E$

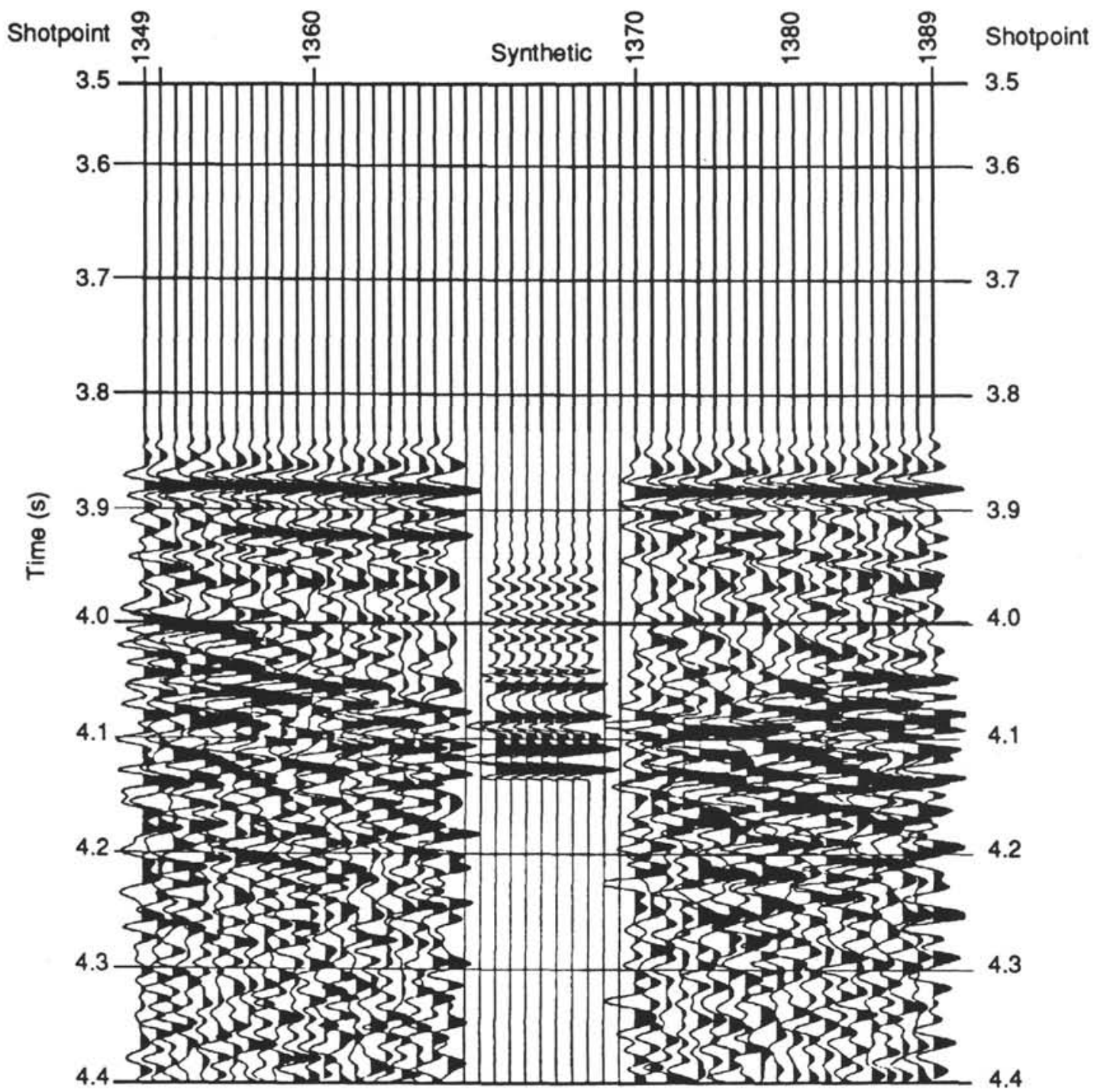

Figure 8. Synthetic seismogram for Hole 835B spliced into a 40-shotpoint segment of migrated JOIDES Resolution seismic line 2. Line location shown in Figure 6.

\section{Site 838}

Site 838 is located in $2323 \mathrm{~m}$ of water in the central Lau Basin, about $87 \mathrm{~km}$ west of the active backarc axis of the ELSC (Figs. 1 and 14). The site cored $259 \mathrm{~m}$ of Pliocene and Pleistocene sedimentary rocks consisting of $23 \mathrm{~m}$ of clayey nannofossil ooze (Unit I, 0-23.04 $\mathrm{mbsf}) ; 75.7 \mathrm{~m}$ of thin to thick-bedded epiclastic volcanic sediments, including coarse vitric sands and gravels with interbedded nannofossil ooze (Unit II, 23.04-98.7 mbsf); and $160.5 \mathrm{~m}$ of poorly sampled sediments and sedimentary rocks including volcanic gravels, sands and conglomerates (Unit III, 98.7-259.2 mbsf). Logging reached only a depth of $220-230 \mathrm{mbsf}$ as a result of filling of the hole bottom during and between logging runs.

JOIDES Resolution seismic reflection line 5 (shotpoints 5880 6050 ) crosses the site at shotpoint 5960 (Fig. 14 and Table 1). The synthetic seismogram for Hole 838B (Fig. 15) shows reflections throughout the section, with the first major reflection at about $70 \mathrm{~ms}$ corresponding to the first appearance of volcanic gravel in the sampled sediments. The base of Unit II and the top of Unit III are marked by several strong reflections between about 90 and $130 \mathrm{~ms}$. The base of Unit II contains volcanic gravel and pebbly coarse vitric sand; the strong reflections on the synthetic seismogram indicate that these units probably extend downward into the poorly sampled Unit III. Several low-amplitude reflections between 130 and $160 \mathrm{~ms}$ possibly correspond to conglomerates or gravels such as those sampled around $150 \mathrm{mbsf}$. A reflection-free zone extends to about $210 \mathrm{~ms}$, possibly indicating a change to a finer grained, more uniform lithology than was present shallower in the hole. High-velocity spikes and a moderate seismic reflection at the base of Unit III may show further conglomerates and gravels deeper in the section. Reflections on the synthetic seismogram correlate reasonably well with dipping reflections on seismic line 5 between 3.15 and $3.3 \mathrm{~s}$ (Figs. 16-17).

\section{Site 839}

Site 839 is located in $2617 \mathrm{~m}$ of water in the central Lau Basin about $70 \mathrm{~km}$ west of the ELSC and about $18.5 \mathrm{~km}$ northeast of Site 838 (Figs. 1 and 14). The site cored $214 \mathrm{~m}$ of Pliocene and Pleistocene sediments 
W

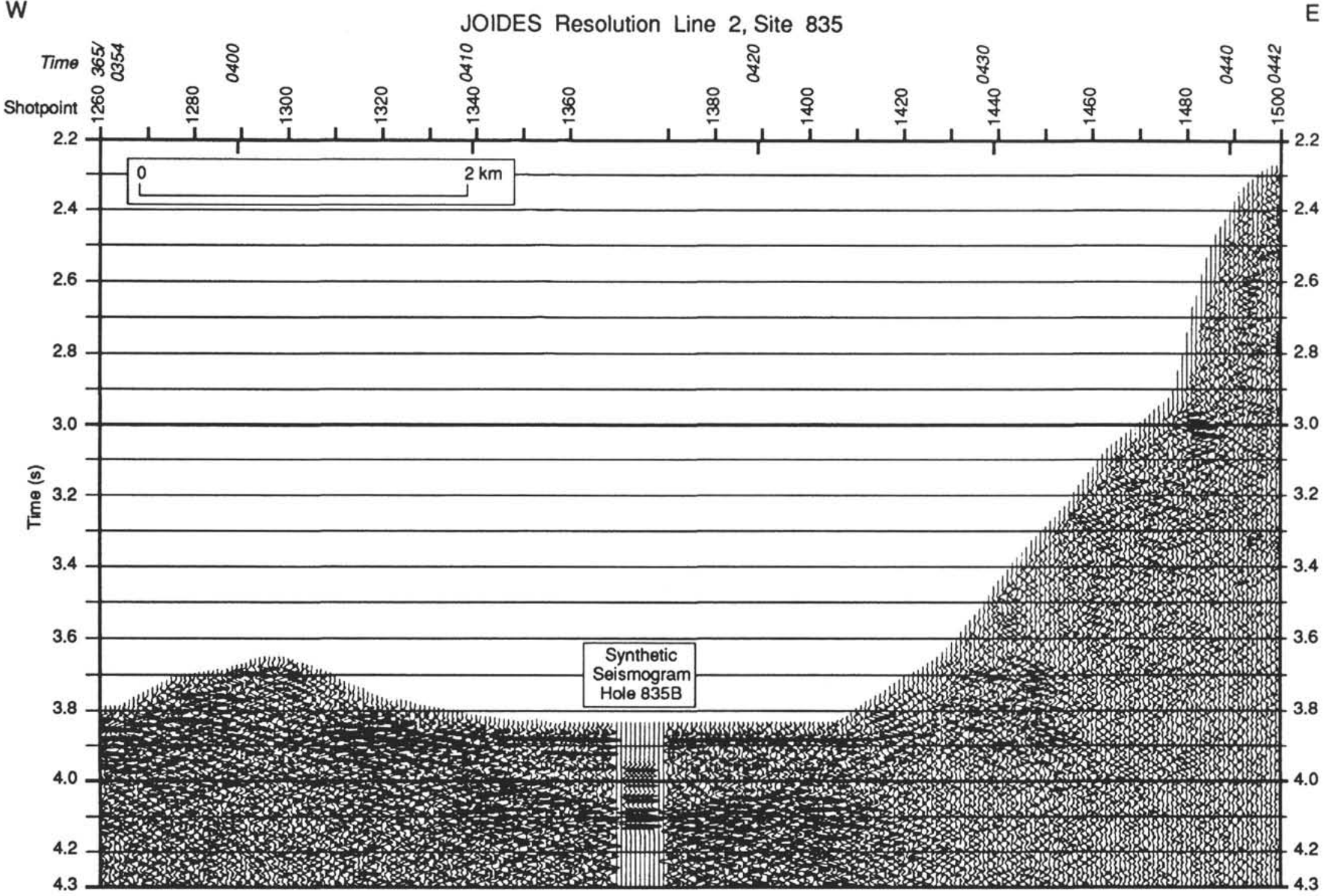

Figure 9. Synthetic seismogram for Hole 835B spliced into migrated JOIDES Resolution seismic line 2, shotpoints 1260-1500. Line location shown in Figure 6. 


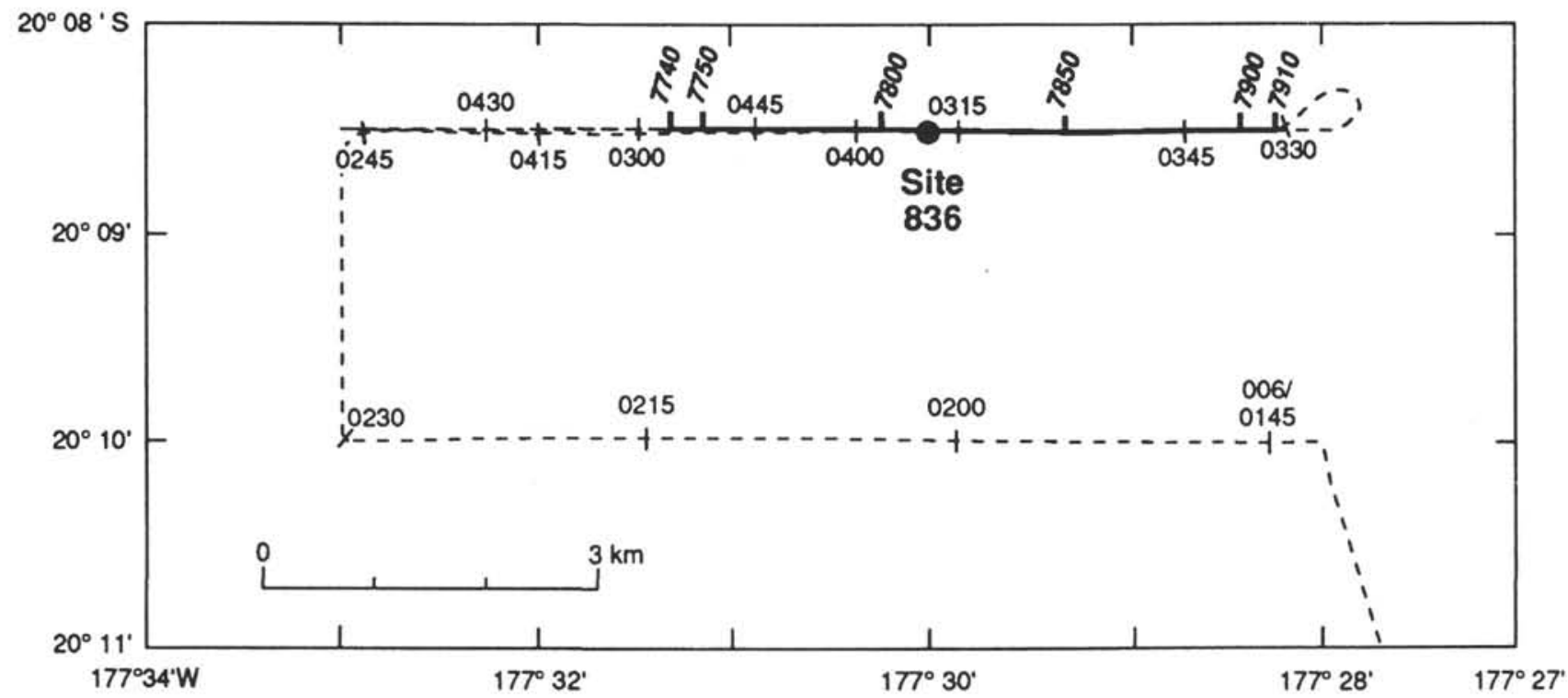

Figure 10. Location of JOIDES Resolution seismic line 3 across Site 836.

and sedimentary rocks overlying basalt, and $283 \mathrm{~m}$ of basalt to a total depth of 517.2 mbsf. Logs were acquired to $473 \mathrm{mbsf}$ (Fig. 18).

JOIDES Resolution seismic reflection line 6, shotpoints 630-867, crosses the site at shotpoint 775 (Fig. 14 and Table 1). On the seismic line (Figs. 19-20), the site is underlain by a sedimentary section that is faulted on the east and dips and thickens westward. A prominent unconformity is present within the sedimentary sequence, and the basement reflection lies at about $3.75 \mathrm{~s}$.

Reflections between 90 and $160 \mathrm{~ms}$ (Fig. 18) arise from the lower part of Unit II (thin- and thick-bedded volcaniclastic vitric sands, silts, gravels, and some clayey nannofossil ooze) and the upper part of Unit III (composed of similar lithologies to Unit II, but not well sampled). These reflections are probably caused by the differences between nannofossil ooze and volcaniclastic sediments. A relatively reflectionfree zone is present between about 160 and $230 \mathrm{~ms}$, which includes the lower two-thirds of Unit II, a poorly sampled section dominated by vitric sand and silt. The seismic data indicates that this part of the sedimentary sequence is lithologically rather uniform or massively bedded. From 230 to $300 \mathrm{~ms}$, a strong series of reflections are caused by the first volcanic unit (Unit 1,214.15-256.81 mbsf) and a sediment interbed (256.81-266.4 mbsf). The basalt unit is massively bedded and has high seismic velocities. Basalt Units $2-8$, between 266.40 and $362.92 \mathrm{mbsf}$, are thin-bedded and characterized by low seismic velocities. This interval, from about 300 to $430 \mathrm{~ms}$ on the synthetic seismogram, produces very low-amplitude reflections. A sequence of strong reflections from 430 to 490 ms corresponds to the upper part of Unit 9 , a high-velocity, thick-bedded basalt unit. Thus, the major basalt reflections are caused by the thick-bedded units.

On seismic line 6 (Fig. 20), the unconformity within the sedimentary sequence at $3.61 \mathrm{~s}$ correlates well with the reflection at about 120 $\mathrm{ms}$ on the synthetic seismogram, which comes from the contact between Units II and III. The strong sequence of reflections from 240 to $300 \mathrm{~ms}$ correlates well with the reflections forming the basal sedimentary sequence and the top of the basalt at $3.75-3.80 \mathrm{~s}$ on the seismic line. Reflections from Unit 9 are present on the seismic line as short, discontinuous reflections between about 3.9 and $4.0 \mathrm{~s}$. For this site, the synthetic seismogram provides an excellent correlation with the seismic reflection profile.

\section{Site 840}

Site 840 is located in $743 \mathrm{~m}$ of water on the crest of the Tonga Ridge about $45 \mathrm{~km}$ northeast of 'Ata Island, and about $130 \mathrm{~km}$ southwest of the islands of Tongatapu and 'Eua (Figs. 1 and 21). Only sedimentary rocks were cored. Unit I (0-109.98 mbsf) consists of interbedded Pliocene and Pleistocene nannofossil ooze with clay, vitric nannofossil ooze with clay, vitric silt, and fine to very coarse grained vitric sand. Unit II (109.98-260.5 mbsf) is composed of late Miocene and early Pleistocene nannofossil chalks and vitric nannofossil chalks interbedded with clay, and grading down into vitric siltstones, vitric sandstones, and thick pumiceous gravel beds. Chalks dominate the sequence from 109.98 to $124.00 \mathrm{mbsf}$, and pumiceous gravels and sandstones dominate the sequence between 124.0 and 260.5 mbsf. Unit III (260.5-597.3 mbsf) consists of late Miocene volcaniclastic turbidites and nannofossil chalks, with volcaniclastic breccias and conglomerates in the lower part of the unit. Logs were acquired at depths of 572 to 527 mbsf in Hole 840B (Fig. 22), with the hole gradually filling during the three logging runs.

S.P. Lee multichannel seismic reflection lines 14 and 8 cross the site (Fig. 21 and Table 1). Line 14 (shotpoints 1890-2070, Figs. 23A and $24 \mathrm{~A}$ ) trends parallel to regional strike, with Hole $840 \mathrm{~B}$ located on the line at shotpoint 1970. Line 8 (shotpoints 1100-1297; Figs. $23 \mathrm{~B}$ and $24 \mathrm{~B}$ ) trends parallel to regional dip and crosses line 14 at shotpoint 2021 about $2.5 \mathrm{~km}$ north of Site 840 . We have projected the synthetic seismogram for Hole $840 \mathrm{~B}$ onto line 8 at shotpoint 1200 based on correlating seismic reflection horizons from line 14. A difficulty in this projection is that a small fault cuts line 14 at about shotpoint 2015 , just before the intersection with line 8 . The character of the seismic reflections on the north side of the fault is slightly different than at Site 840 , and the fit of the synthetic seismogram reflections to the observed reflections on line 8 is not as good, therefore, as the fit on line 14 .

The generally reflective character of the synthetic (Fig. 22) is probably a result of alternating lithologies of chalk, turbidite sands, and gravels as well as the presence of thick vitric gravel beds throughout the drilled section. The synthetic seismogram shows no particular correlation to the Unit II/III boundary.

The correlation of the synthetic seismogram to line 14 (Figs. 23A and $24 \mathrm{~A}$ ) is particularly good between about 150 and $260 \mathrm{~ms}$ on the synthetic and from 1.2 to $1.3 \mathrm{~s}$ on line 14 . Positive reflections on the synthetic at $150-160,200-210$, and $240-250 \mathrm{~ms}$ are separated by wide negative excursions; the reflection intervals match very well with reflections on the seismic record. Reflections on the synthetic between about 260 and $370 \mathrm{~ms}$, however, are a higher frequency than those observed on the seismic data between about 1.3 and $1.42 \mathrm{~s}$. The generally reflection-free part of the synthetic between 375 and 425 
W

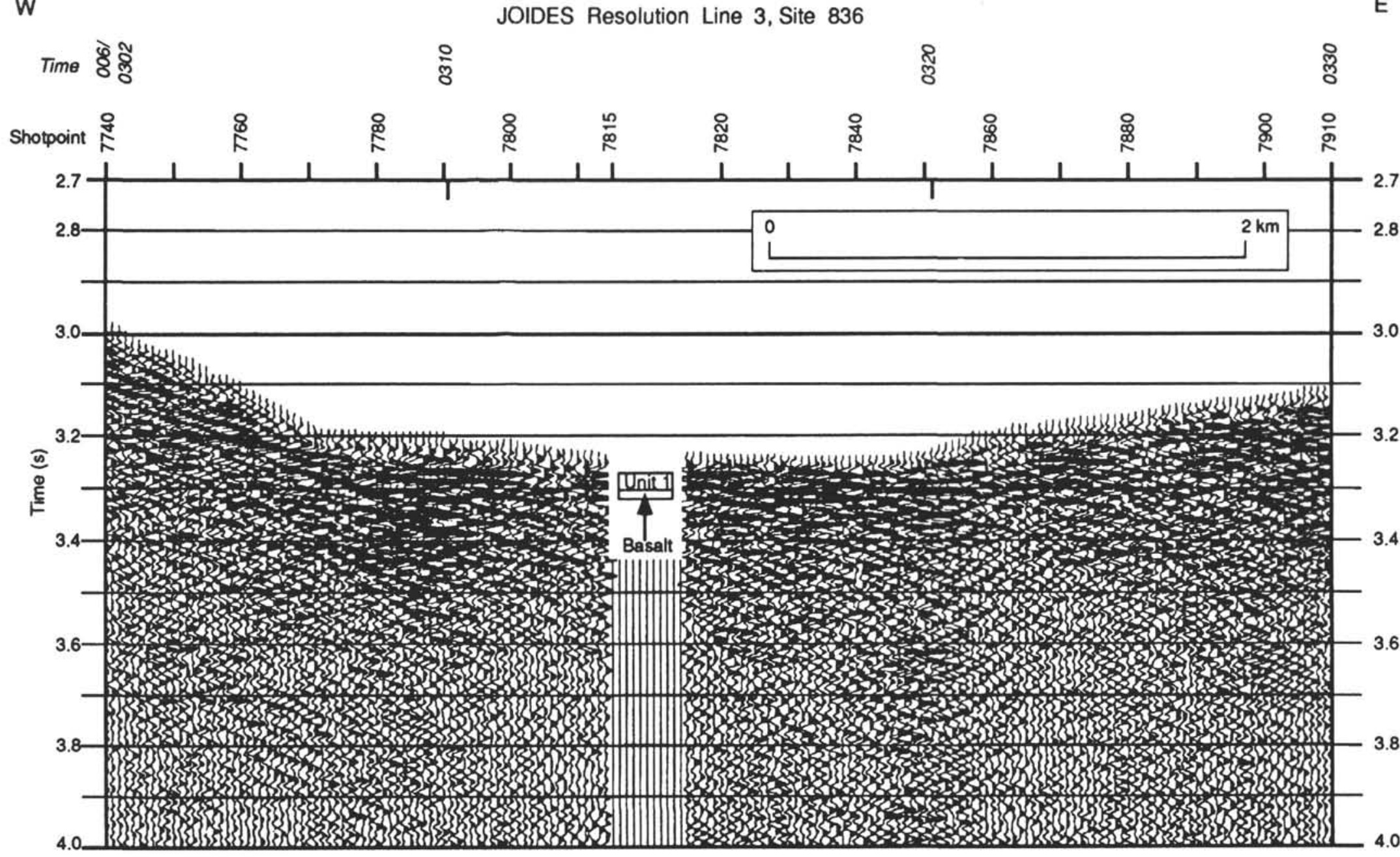

Figure 11. Migrated JOIDES Resolution seismic line 3, shotpoints 7740-7910, across Site 836, with simplified lithologic column spliced in at site location, shotpoint 7814. Line location shown in Figure 10. 


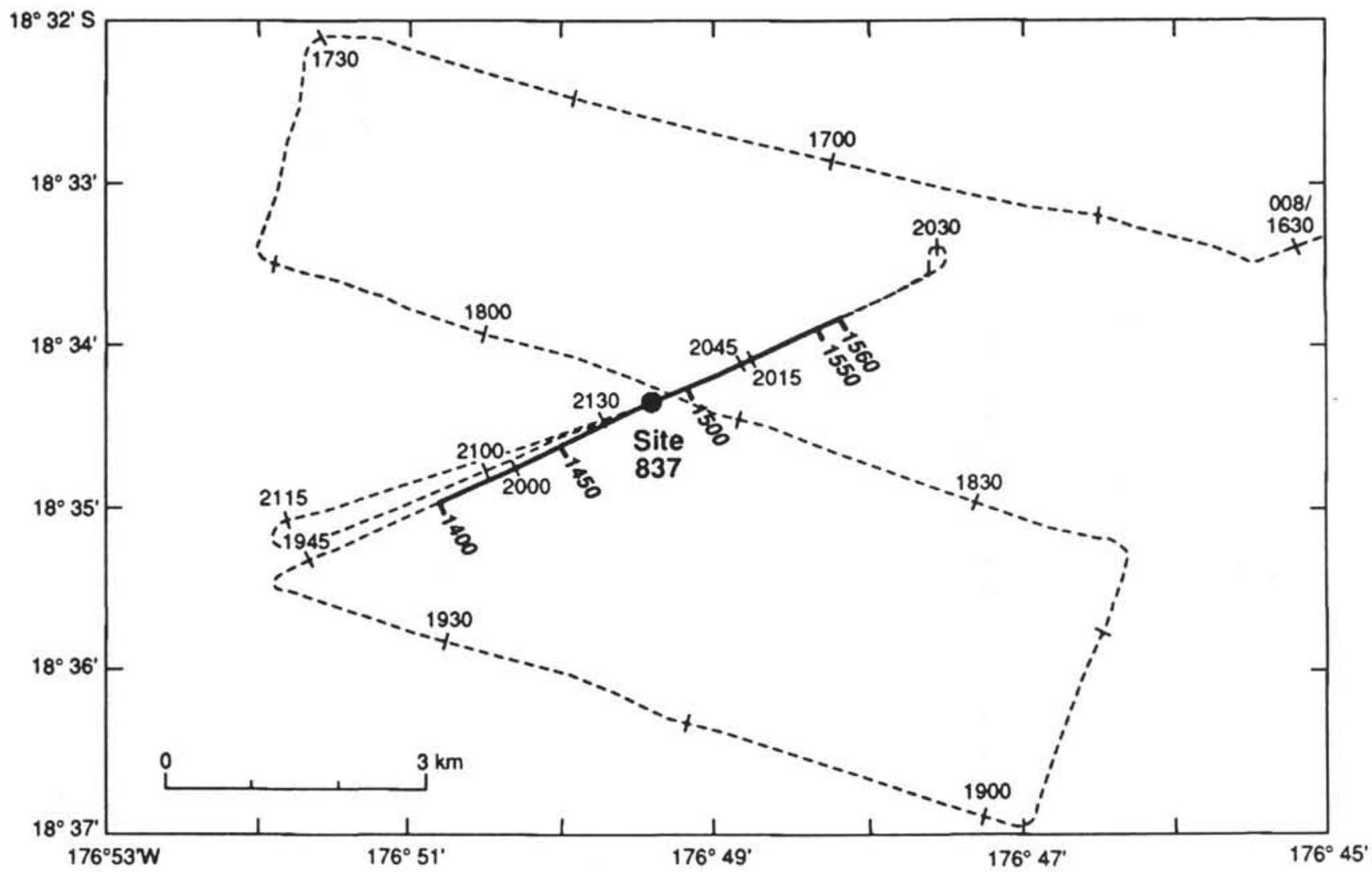

Figure 12. Location of JOIDES Resolution seismic line 4 across Site 837.

ms, however, correlates well with an interval on the seismic line between 1.4 and $1.5 \mathrm{~s}$. The reflections between 200 and $380 \mathrm{~ms}$ are caused by the thick vitric gravel sequences sampled in the borehole.

The reflection events beginning at about $430 \mathrm{~ms}$ (about $400 \mathrm{mbsf}$ ) correspond to a zone of increasing velocity and density noted in the Initial Reports volume for Site 840 (Parson, Hawkins, Allan, et al., 1992). This change in physical properties also corresponds to a zone of alteration from 367 to about $430 \mathrm{mbsf}$, with carbonate dissolution and where pore spaces are filled with clay minerals and zeolites, and to Horizon A, a major target for the drill hole and an unconformity that extends throughout the southern Tonga platform (Tappin et al., in press). The combination of seismic unconformity and sediment alteration could indicate subaerial exposure and nondeposition or erosion as the cause of the unconformity (see Tappin et al., this volume).

A reflection-free zone on the synthetic at about $540-550 \mathrm{~ms}$ matches another change in physical properties, in this case decreasing velocity and density values. The section between 490 and $500 \mathrm{mbsf}$ corresponding to this decrease could contain an unconformity, as dip measurements below $500 \mathrm{mbsf}$ range as high as $20^{\circ}$ whereas dips above $490 \mathrm{mbsf}$ are mainly $<2^{\circ}$. This dip change is observed on line 8 (Fig. 24B) as a gentle unconformity, but the unconformity is not evident on line 14 (Fig. 24A). The correlation of synthetic reflections to seismic reflections is moderately good below $1.5 \mathrm{~s}$, although the reflection frequency is somewhat higher on the synthetic than on the seismic data.

The correlation of the synthetic seismogram with line 8 (Fig. 23B and 24B) is not as good as with line 14. The major reasons for this are (1) a slight thickening of the sedimentary sequences northward along line 14 to its intersection with line 8 , (2) a significant change in reflection character across a small fault that is present on line 14 just southwest of the intersection with line 8 , and (3) a change in reflection character between lines 8 and 14. Presumably, these changes are caused by rapid variations in lithology, such as thinning or thickening of vitric gravel and sand beds. For example, a seismic unit on line 14 defined by reflections at 1.2 and $1.25 \mathrm{~s}$ below shotpoint 1970 thickens northeastward to include an intermediate reflection; the unit then lies between 1.17 and 1.25 s below shotpoint 2010 adjacent to the small fault. This indicates an increase in sediment thickness of about $30 \mathrm{~m}$ in a distance of about $2 \mathrm{~km}$. Similarly, the reflection event from 1.25-1.30 $\mathrm{s}$ at shotpoint 1970 on line 14 thins out southward by shotpoint 1950 by onlap against a small structural, fault-bounded high. The reflection character of the seismic reflection data also commonly changes across the numerous small faults that cut the section, for example, below shotpoints 2060,2080, and 2090 on line 14.

\section{Site 841}

Site 841 was drilled on the upper trench slope, west of the axis of the Tonga Trench, in a water depth of $4810 \mathrm{~m}$ (Figs. 1 and 25). From 0 to $605 \mathrm{mbsf}$, Hole 841B cored late Eocene through Pleistocene sedimentary rocks cut by Miocene basalt dikes; from 605 to $832 \mathrm{mbsf}$, rocks are from a rhyolitic-dacitic complex of unknown age. Logging data were acquired to total depths of between 545 and $555 \mathrm{mbsf}$ in Hole 841 C (Fig. 26). S.P. Lee line 12, shotpoints 1700-1880, crosses the site at shotpoint 1758 (Table 1 and Figs. 27A and 28A). JOIDES Resolution seismic reflection line 8 (Table 1 and Figs. 27B-27C and $28 \mathrm{~B}-28 \mathrm{C}$ ) crosses the site twice (Fig. 25), with a downslope crossing between shotpoints 220 and 420 (borehole at shotpoint 267), and a slope parallel crossing between shotpoints 840 and 1020 (borehole at shotpoint 931).

Synthetic seismograms were computed to match the multichannel and single-channel seismic reflection data (Fig. 26). The two seismograms differ for two main reasons. First, the polarity of the multichannel synthetic seismogram is opposite to the single-channel seismogram 


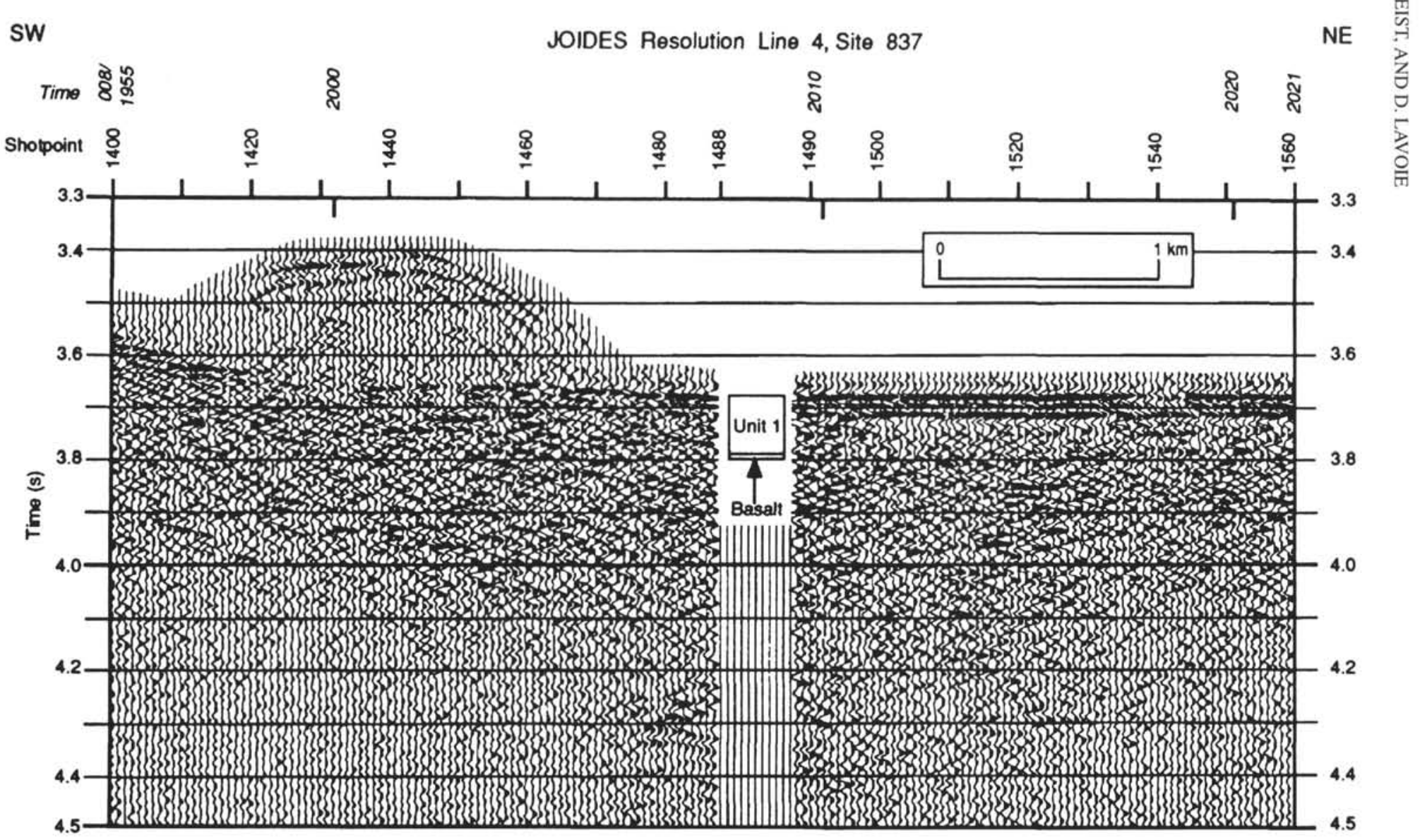

Figure 13. Migrated JOIDES Resolution seismic line 4, shotpoints 1400-1560, across Site 837, with simplified lithologic column spliced in at site location, shotpoint 1487. Line location shown in Figure 12. 


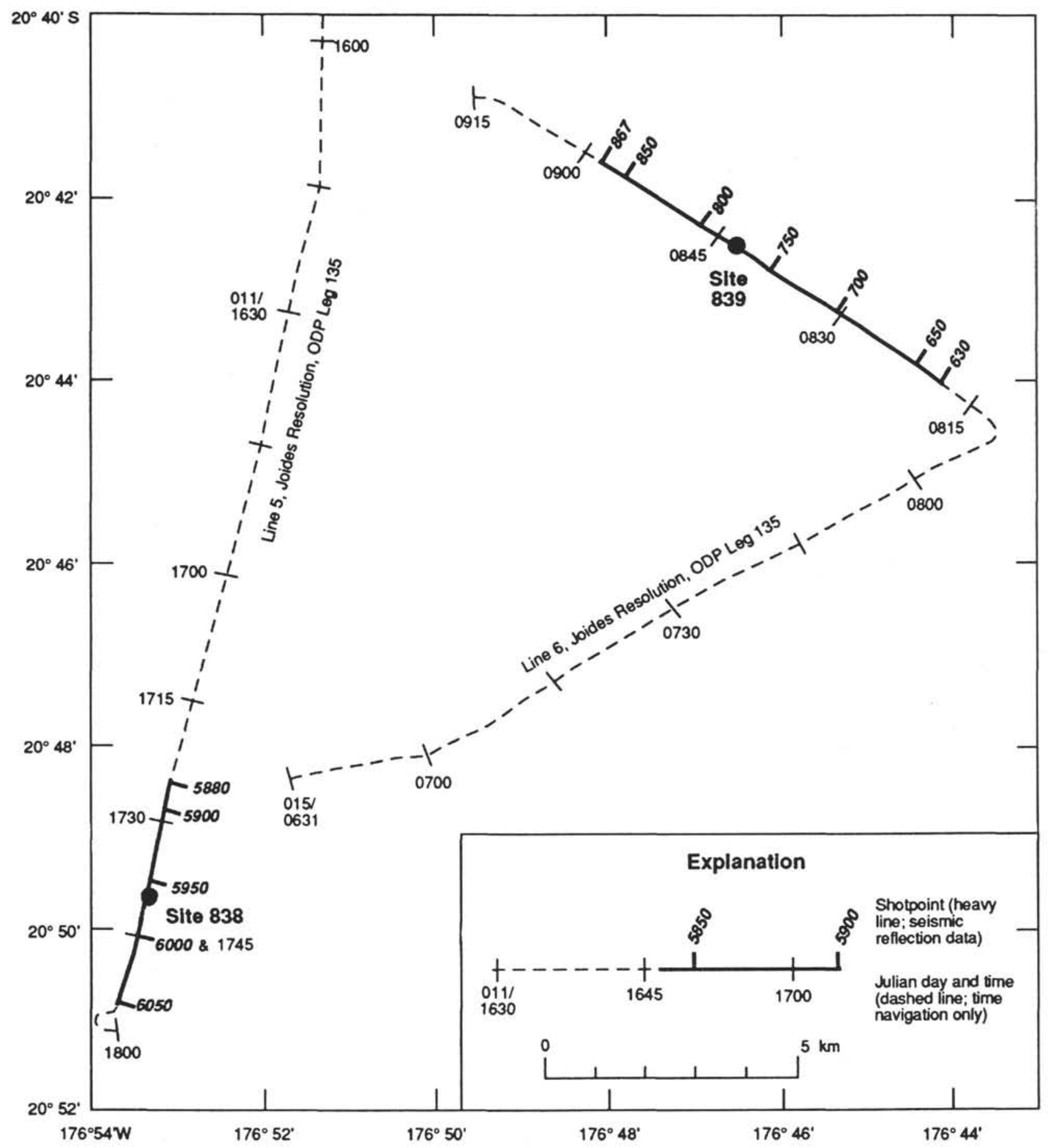

Figure 14. Location of JOIDES Resolution seismic lines 5 and 6 across Sites 838 and 839.

to achieve the best fit with the pulse recorded on the S.P. Lee data. The result is that the major positive amplitude reflections on the multichannel-based seismogram are shifted downward by about $20 \mathrm{~ms}$ relative to the single-channel seismogram (Fig. 26). Second, shifts in the position of the calculated reflections are a result of the differing dominant frequencies of the two kinds of data $(25 \mathrm{~Hz}$ for multichannel seismic; $45 \mathrm{~Hz}$ for single-channel seismic).

Major reflections at about 125 and $260 \mathrm{~ms}$ (single-channel seismic) or 145 and $280 \mathrm{~ms}$ (multichannel seismic) arise from abrupt downhole increases in the average sonic velocity at 117 and $247 \mathrm{mbsf}$ (Fig. 26). These reflections lie within Unit II (interbedded clay with glass, and vitric silt and sand), but no distinct lithologic changes were noted on core or logs from the unit that might cause the reflections. At $117-130 \mathrm{mbsf}$, the only change in lithology corresponding to the upper reflection is an increase in the amount of clay below $130 \mathrm{mbsf}$. No significant change in the lithology occurs at $245 \mathrm{mbsf}$, corresponding to the 260-290 ms reflection.

The velocity and density contrast between Units II and III (volcanic conglomerate interbedded within vitric siltstone and sandstones) creates three reflections at 325-375 ms on the single-channel seismogram, but produces no reflection on the multichannel seismogram (Fig. 26). Velocity and density changes at a major fault at $458 \mathrm{mbsf}$ correspond 


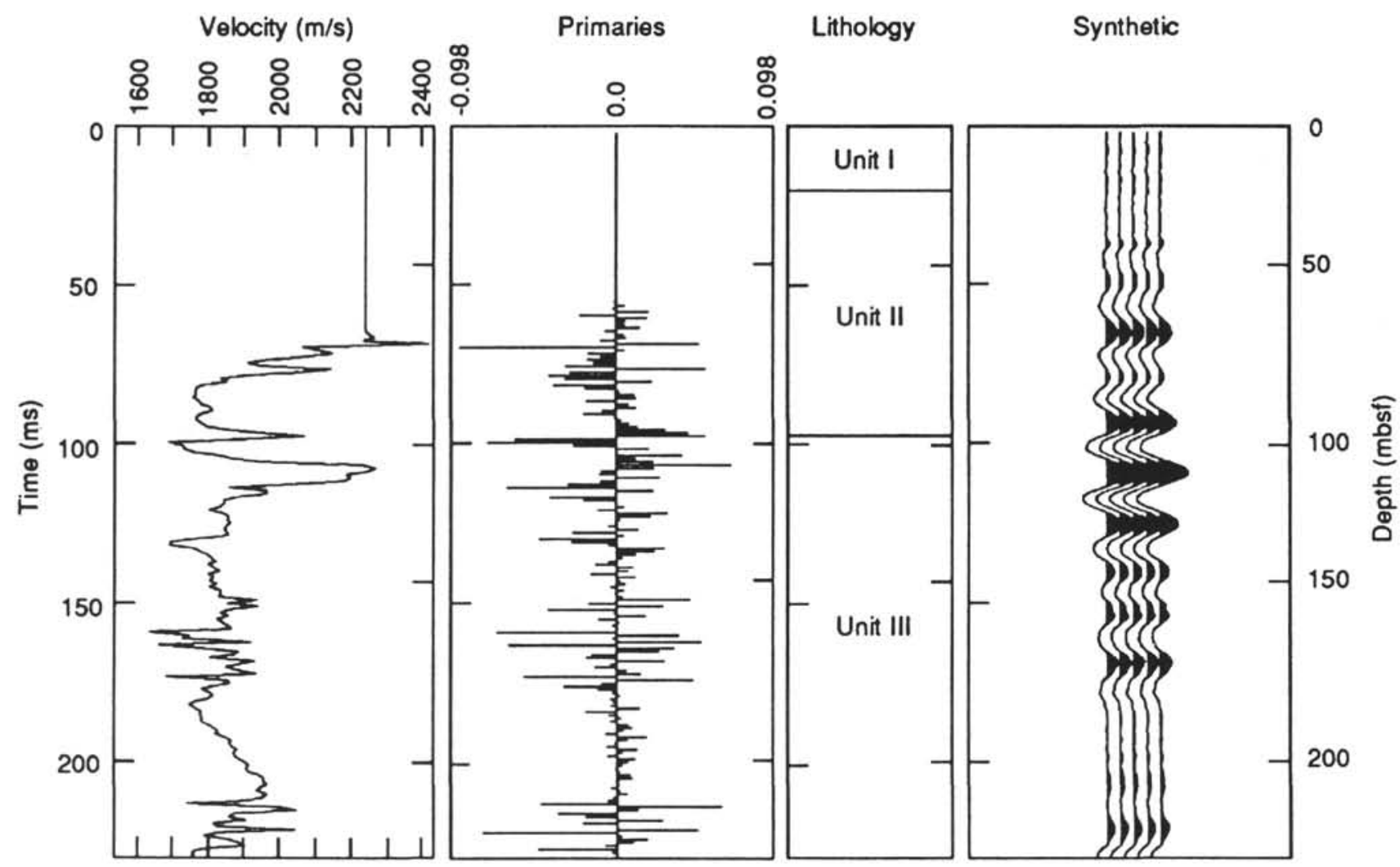

Figure 15. Plot of sonic velocity from logging data $(\mathrm{m} / \mathrm{s})$, plot of calculated reflection coefficients, simplified lithologic column, and synthetic seismogram for Hole 838B. Lithologic column is from Parson, Hawkins, Allan, et al. (1992, pp. 337-395). Two-way traveltime in ms annotated on left side of each column, and depth in mbsf annotated on right side.

to high-amplitude reflections centered on about $425 \mathrm{~ms}$ on the singlechannel seismogram and about $440 \mathrm{~ms}$ on the multichannel seismogram. Numerous thin basalt dikes were penetrated in the interval from 342 to $450 \mathrm{mbsf}$, and were especially common from 375 to 419 mbsf. These dikes do not have corresponding individual reflections, but combine together to create several low-amplitude reflections between about 375 and $410 \mathrm{~ms}$ on the single-channel seismogram and a strong reflection at about $440 \mathrm{~ms}$ on the multichannel seismogram.

The synthetic seismograms show only a poor correlation with reflections on the seismic lines, in part because the seismic reflection data have few continuous reflections. The lack of correlations is also likely a result of rapid lithologic changes, extensive minor faulting, and the large area sampled by the seismic reflection data compared with the small area of the borehole. On multichannel line 12 (Figs. $27 \mathrm{~A}$ and $28 \mathrm{~A}$ ), few good continuous reflections are present near Site 841. Reflections from the upper $0.5 \mathrm{~s}$ of the seismic record could come from clay-dominated Unit I, which lies entirely above the computed synthetic seismogram. The strong upper reflection from within Unit II correlates with a weak, westward-dipping reflection at about $6.6 \mathrm{~s}$. Other reflections on the synthetic seismogram correlate only poorly with reflections on the seismic record. A strong reflection on the seismic profile at $7.0 \mathrm{~s}$ probably correlates with a major fault penetrated at 605 mbsf; this fault separated sedimentary rocks from highly altered rhyolitic igneous rocks.

On the downslope portion of single-channel line 8 (Figs. 27B and 28B), the upper reflection from within Unit II correlates strongly with a flat-lying to trenchward-dipping unit at about $6.58-6.6 \mathrm{~s}$. The fault zone reflection at $6.9 \mathrm{~s}$ correlates to the top of a poorly defined zone of westward-dipping reflections; the top of this set of reflections appears to outcrop on the slope at about $6.8 \mathrm{~s}$ beneath shotpoint 430 . On the slope-parallel segment of single-channel line 8 (Figs. 27C and
$28 \mathrm{C}$ ), indistinct, discontinuous reflections lie between about 6.7 and $7 \mathrm{~s}$; the reflections from rocks at the top of Unit III to below the fault zone roughly correspond to this fuzzy band. The fault zone reflection appears to lie within the lower part of this band, and the base of the band may lie at about the 605 -mbsf fault horizon or at about $7.0 \mathrm{~s}$ on the seismic reflection data.

\section{SUMMARY}

For Leg 135 sites, the match between synthetic seismograms and real data is variable. Along lines crossing Sites 834-835 and 838-840, some excellent correlations are present, particularly at unit boundaries and with basement basalt. Some of the reflections observed also correlate with conglomeratic units and beds of coarse vitric gravel or sand. A seismic unconformity present within the sedimentary section at Site 839 corresponds to a synthetic seismogram reflection arising from the Unit I/II contact at that site. Observed reflections correlate to synthetic reflections arising from sedimentary interbeds within basalt at Site 834 but not at Site 839. Observed reflections are also associated with basalts within the sedimentary section at Site 841 . For Site 841, the match of the synthetic seismogram to real data is poor, primarily because of the absence of continuous reflections on the seismic data. Poor correlations between synthetic and real data are also caused by rapid lithologic changes at Site 840 , and probably by a combination of poorly reflective data, rapid lithologic changes, and complex structure at Site 841.

\section{ACKNOWLEDGMENTS}

We thank M.A. Fisher and M.S. Marlow for their reviews. D. Lavoie's work was supported by NRL program element number $61153 \mathrm{~N}$. 


\section{REFERENCES}

Lindseth, R.O., 1979. Synthetic sonic logs-a process for stratigraphic interpretation. Geophysics, 44:3-26.

Mann, D.M., 1985. Multichannel profiles collected in 1982 in the Tonga region of the South Pacific. In Scholl, D.W., and Vallier, T.L. (Eds.), Geology and Offshore Resources of Pacific Island Arcs-Tonga Region. Circum-Pac. Counc. Energy Miner. Resourc., Earth Sci. Ser., 2:49-54.

Parson, L., Hawkins, J., Allan, J., et al., 1992. Proc. ODP, Init. Repts., 135: College Station, TX (Ocean Drilling Program).

Scholl, D.W., and Vallier, T.L. (Eds.), 1985. Geology and Offshore Resources of Pacific Island Arcs-Tonga Region. Circum-Pac. Counc. Energy Miner. Resour., Earth Sci. Ser., 2.

Steele, W.C., Kinoshita, K.L., and Stevenson, A.J., 1985. Navigation data collection, processing, and display. In Scholl, D.W., and Vallier, T.L.,
Geology and Offshore Resources of Pacific Island Arcs-Tonga Region. Circum-Pac. Counc. Energy Miner. Resour., Earth Sci. Ser., 2:25-26.

Tappin, D.R., Herzer, R.H., and Stevenson, A.J., in press. Structure and history of an oceanic forearc-The Tonga Ridge $22^{\circ}$ to $26^{\circ}$ South. In Stevenson, A.J., and Ballance, P. (Eds.), Tonga Arc. Circum-Pac. Counc. Energy Miner. Resour. and CCOP/SOPAC Earth Sci. Ser.

"Abbreviations for names of organizations and publication titles in ODP reference lists follow the style given in Chemical Abstracts Service Source Index (published by American Chemical Society)

Date of initial receipt: 30 June 1992

Date of acceptance: 7 June 1993

Ms 135SR-156

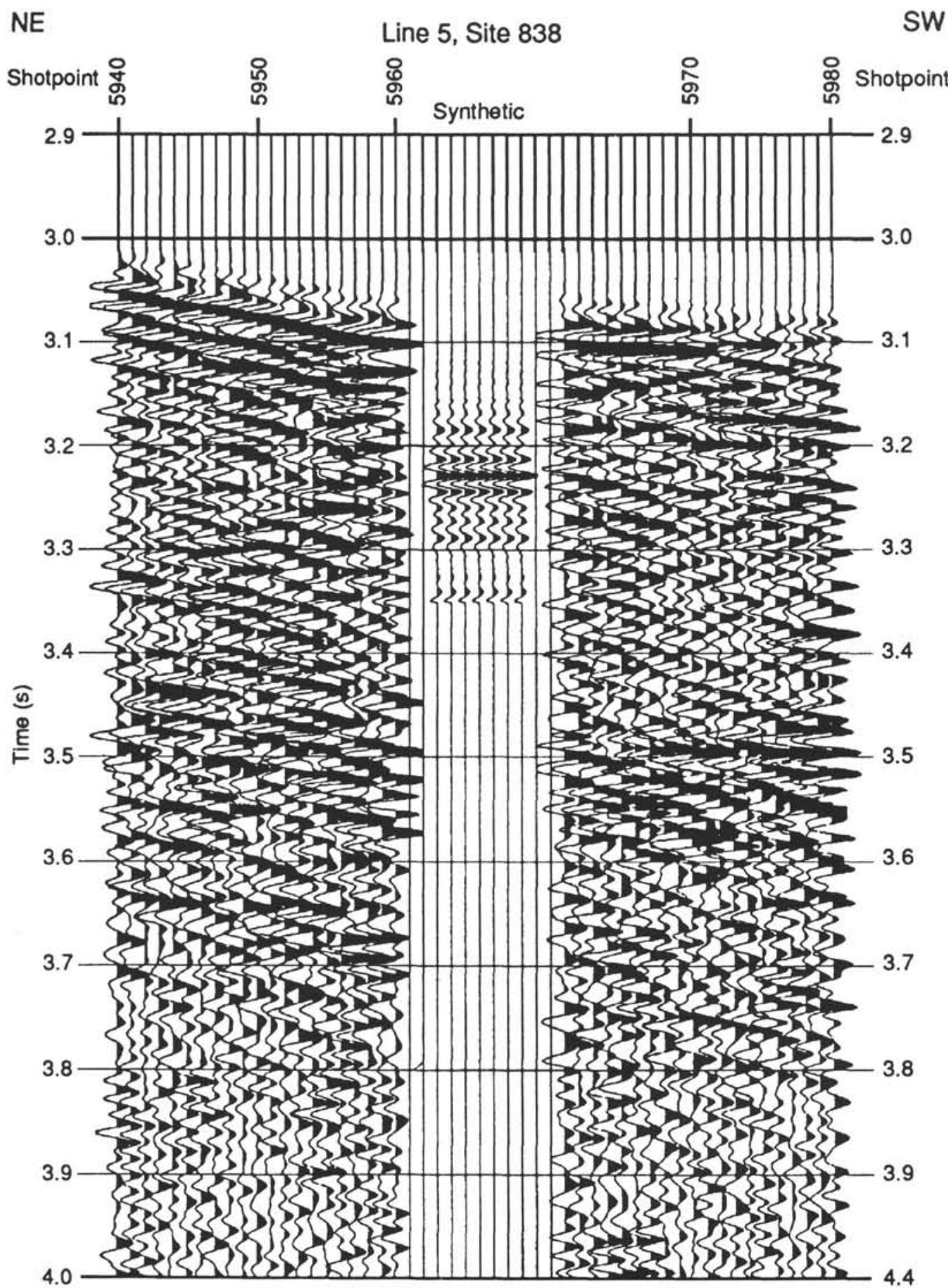

Figure 16. Synthetic seismogram for Hole 838B spliced into a 40-shotpoint segment of migrated JOIDES Resolution seismic line 5. Line location shown in Figure 14. 
$\mathrm{N}$

JOIDES Resolution Line 5, Site 838

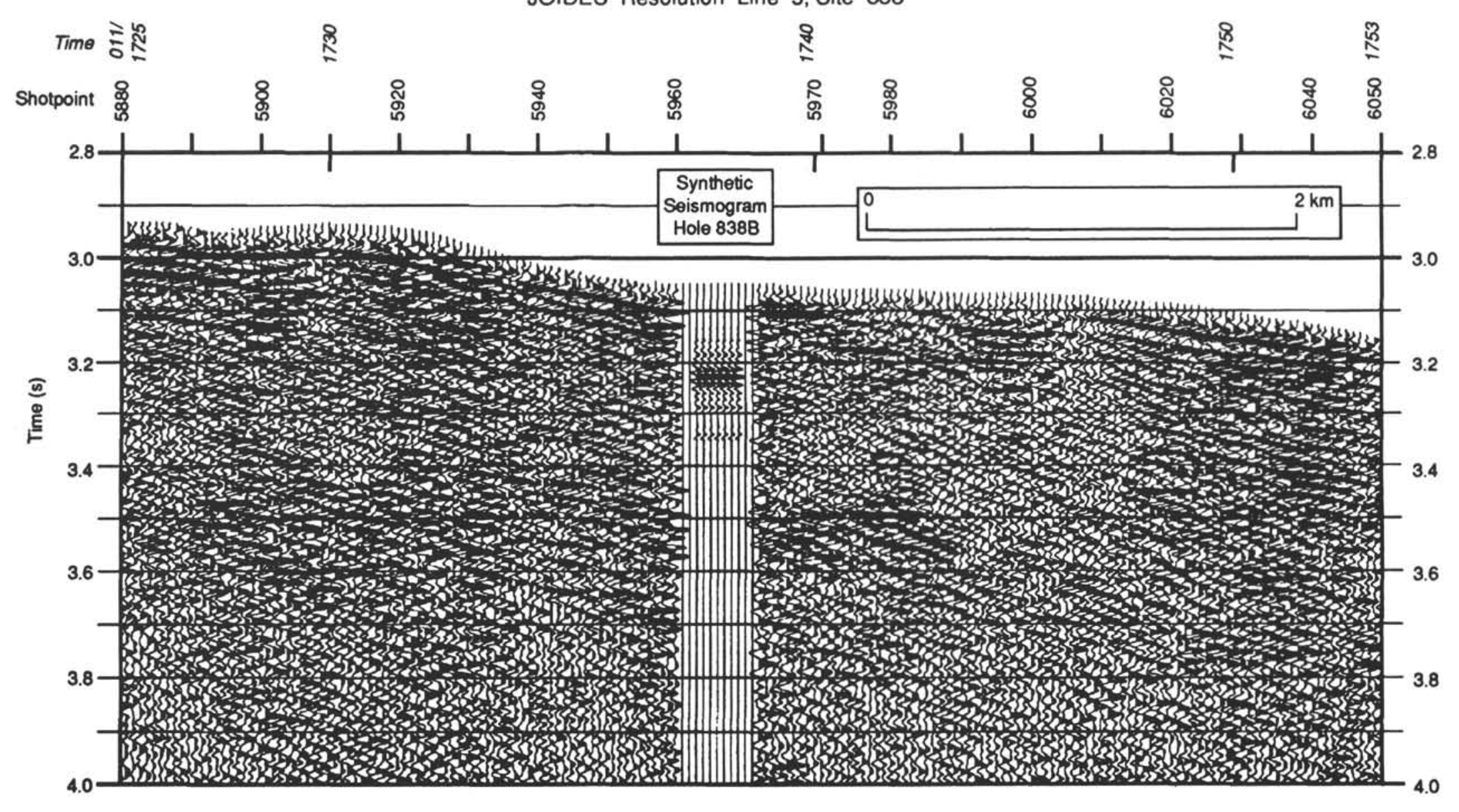

Figure 17. Synthetic seismogram for Hole 838B spliced into migrated JOIDES Resolution seismic line 5, shotpoints 5880-6050. Line location shown in Figure 14. 


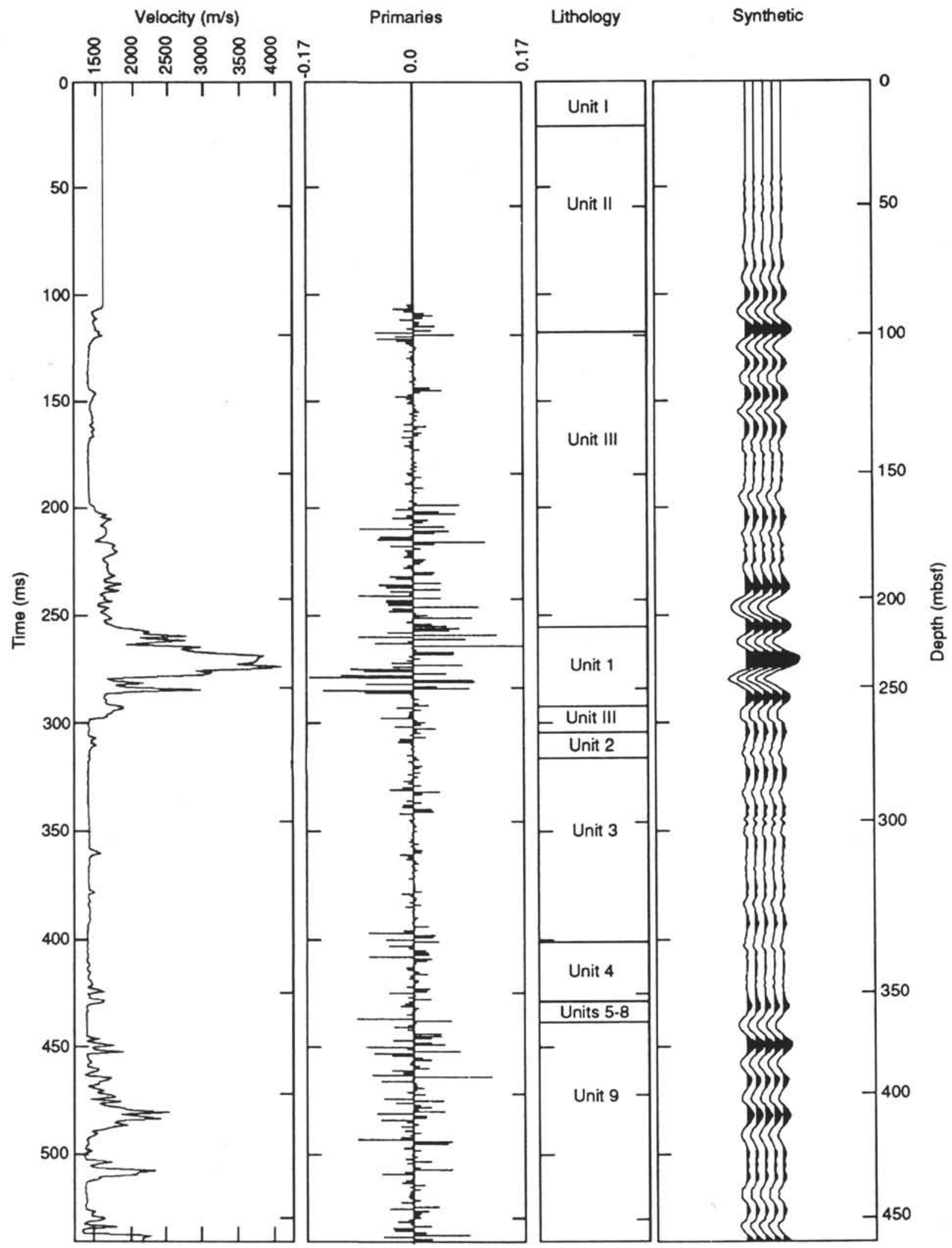

Figure 18. Plot of sonic velocity from logging data $(\mathrm{m} / \mathrm{s})$, plot of calculated reflection coefficients, simplified lithologic column, and synthetic seismogram for Hole 839B. Lithologic column is from Parson, Hawkins, Allan, et al. (1992, pp. 397-487). Two-way traveltime in ms annotated on left side of each column, and depth in mbsf annotated on right side. 
NW

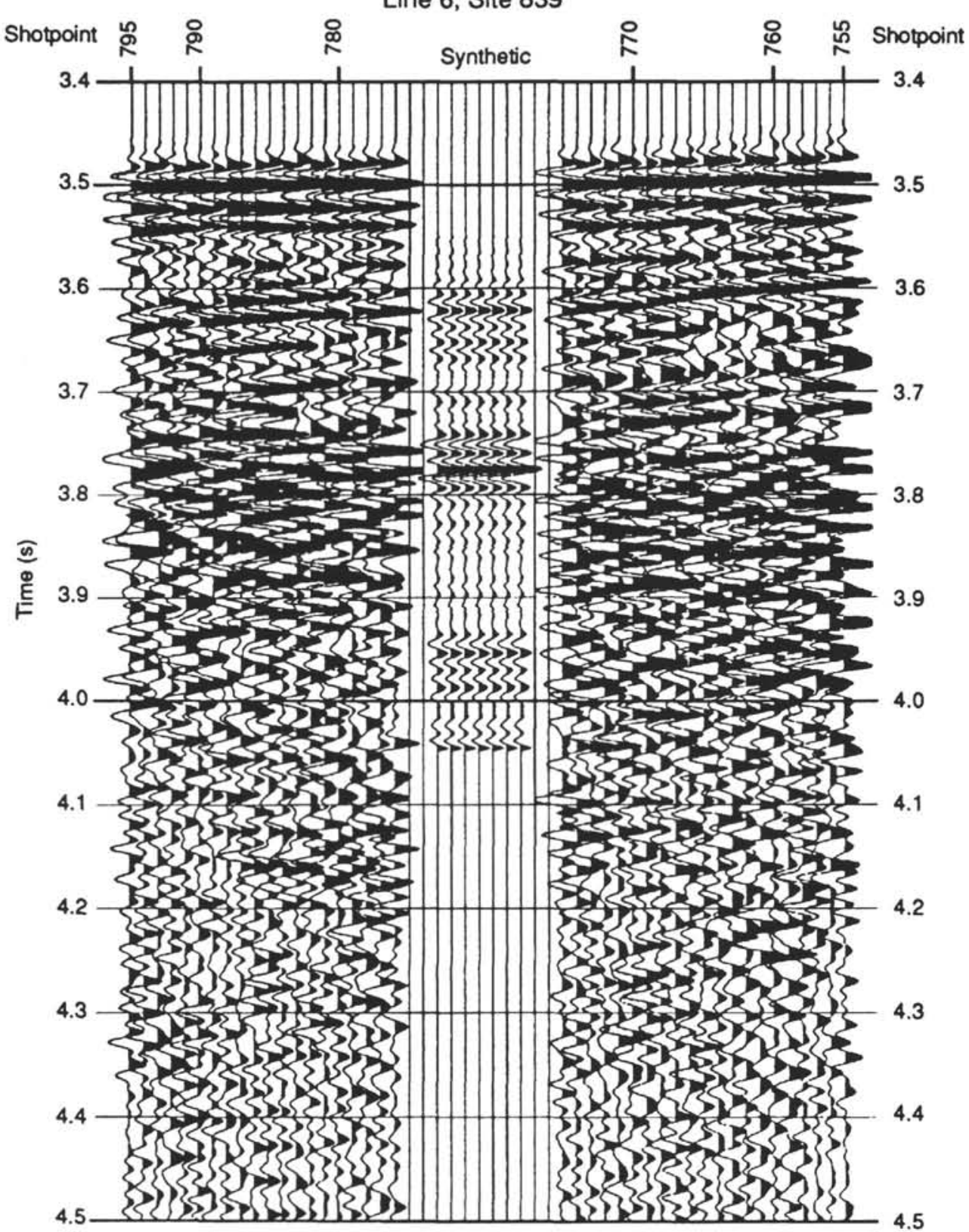

Figure 19. Synthetic seismogram for Hole 839B spliced into a 40-shotpoint segment of migrated JOIDES Resolution seismic line 6. Line location shown in Figure 14. 


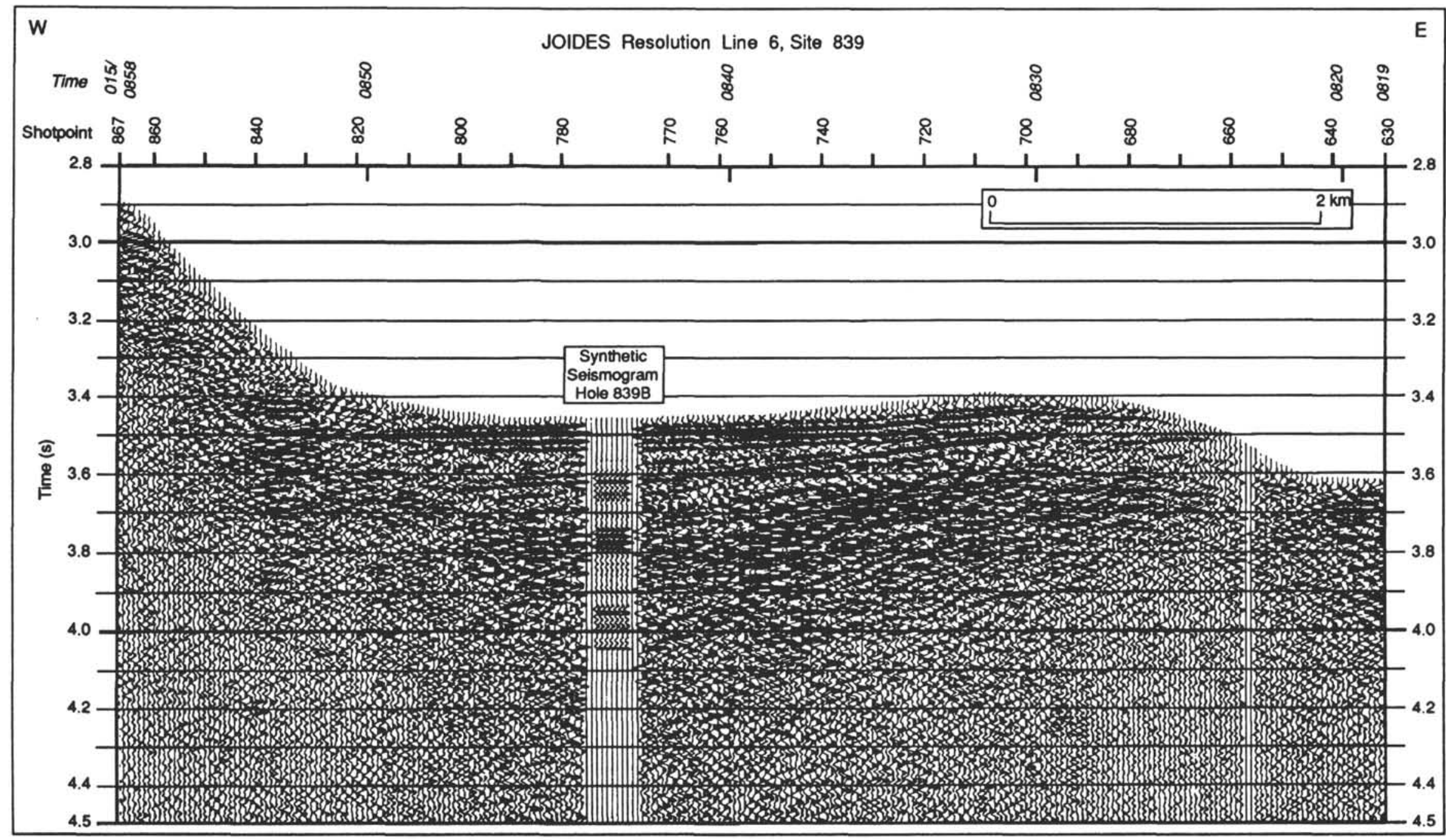

Figure 20. Synthetic seismogram for Hole 839B spliced into migrated JOIDES Resolution seismic line 6, shotpoints 630-867. Line location shown in Figure 14. 


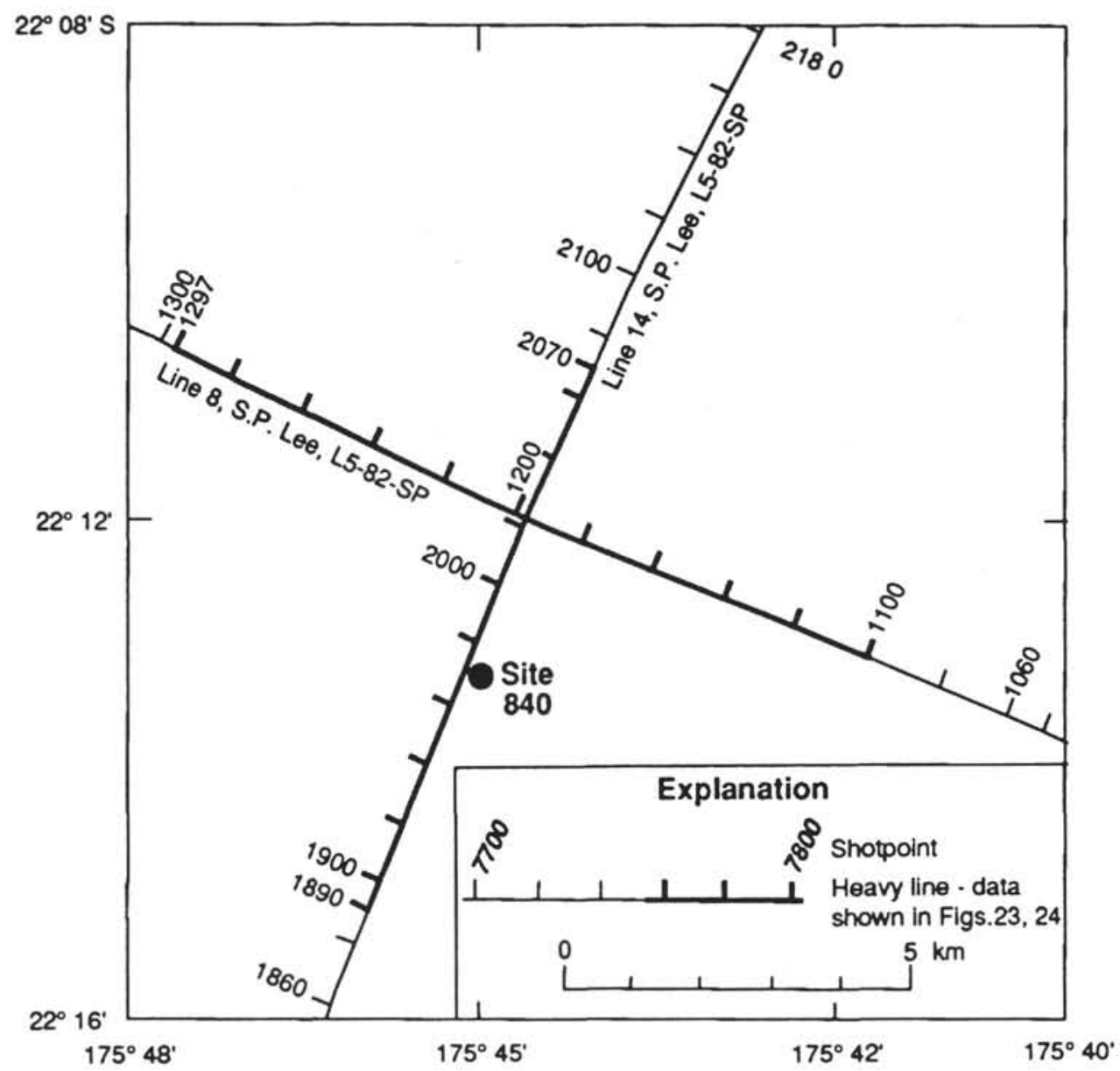

Figure 21. Location of S.P. Lee multichannel seismic lines 8 and 14 across Site 840 (Scholl and Vallier, 1985). 


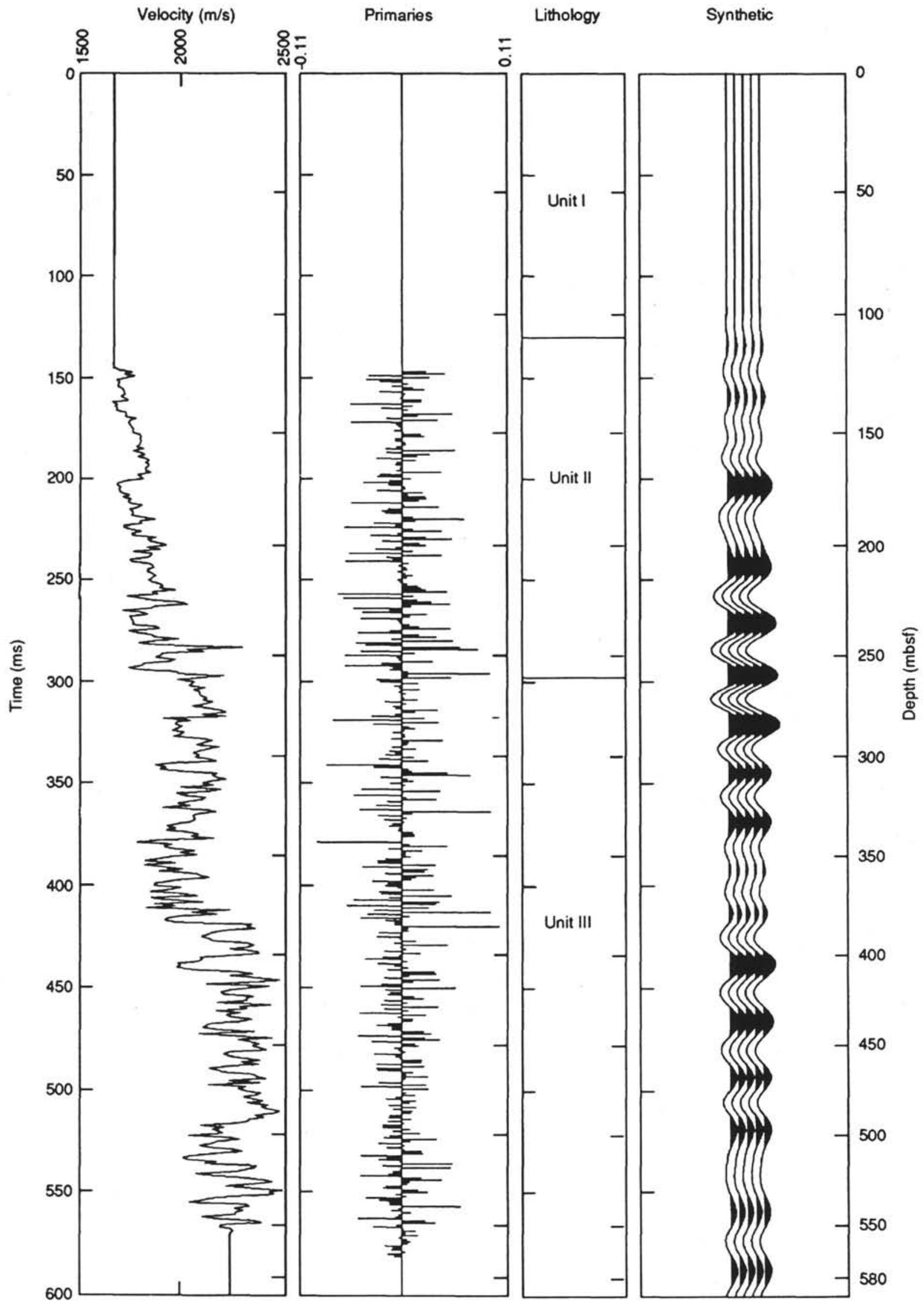

Figure 22. Plot of sonic velocity from logging data $(\mathrm{m} / \mathrm{s})$, plot of calculated reflection coefficients, simplified lithologic column, and synthetic seismogram for Hole 840B. Lithologic column is from Parson, Hawkins, Allan, et al. (1992, pp. 489-571). Two-way traveltime in ms annotated on left side of each column, and depth in mbsf annotated on right side. 
A SW

Multichannel Line 14, Site 840

NE

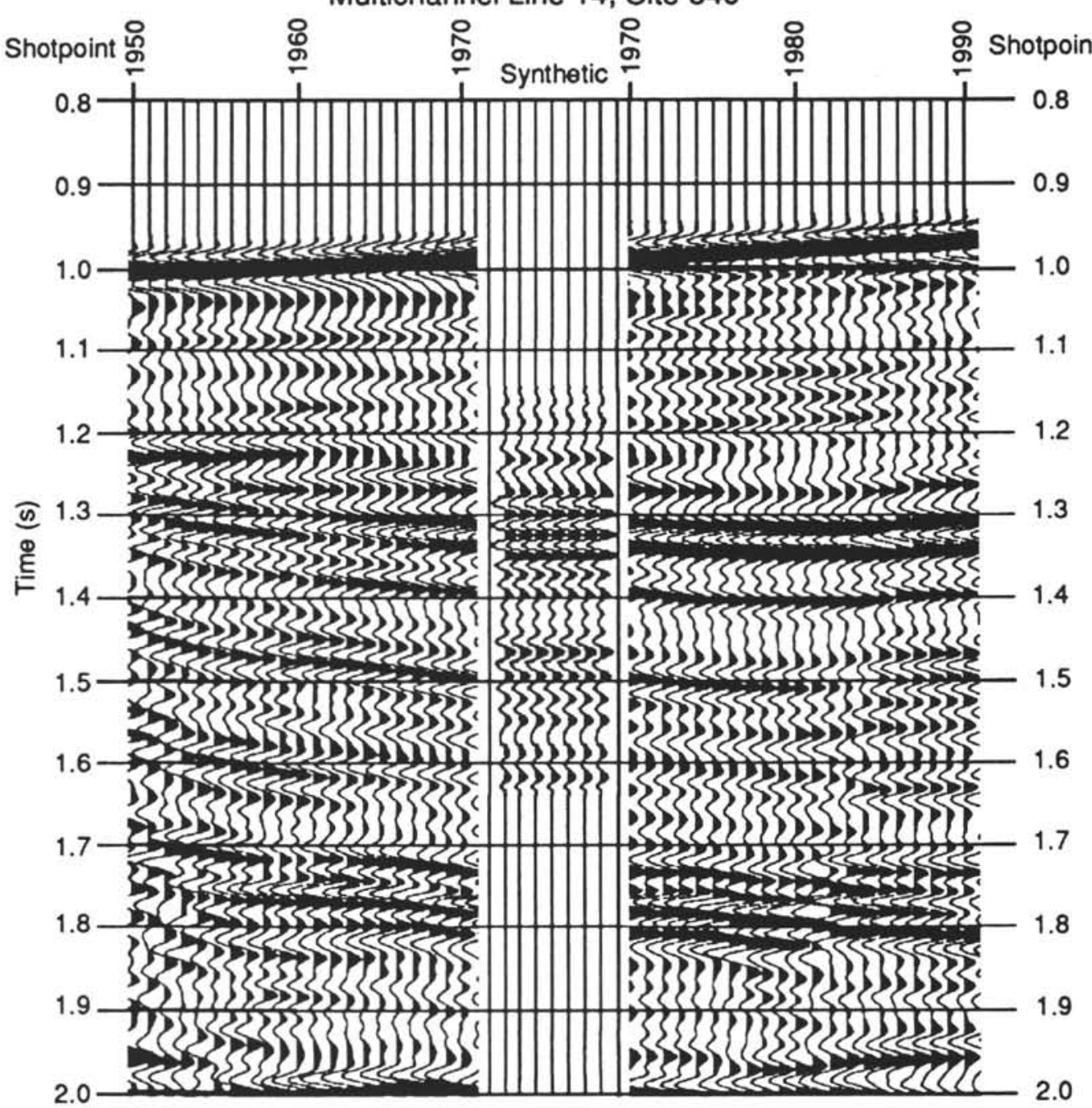

Figure 23. Synthetic seismogram for Hole 840B spliced into a 40-shotpoint segment of migrated S.P. Lee seismic line 14 (A) and migrated S.P. Lee seismic line 8 (B). Line locations shown in Figure 21. 
B W

Multichannel Line 8, Site 840

E

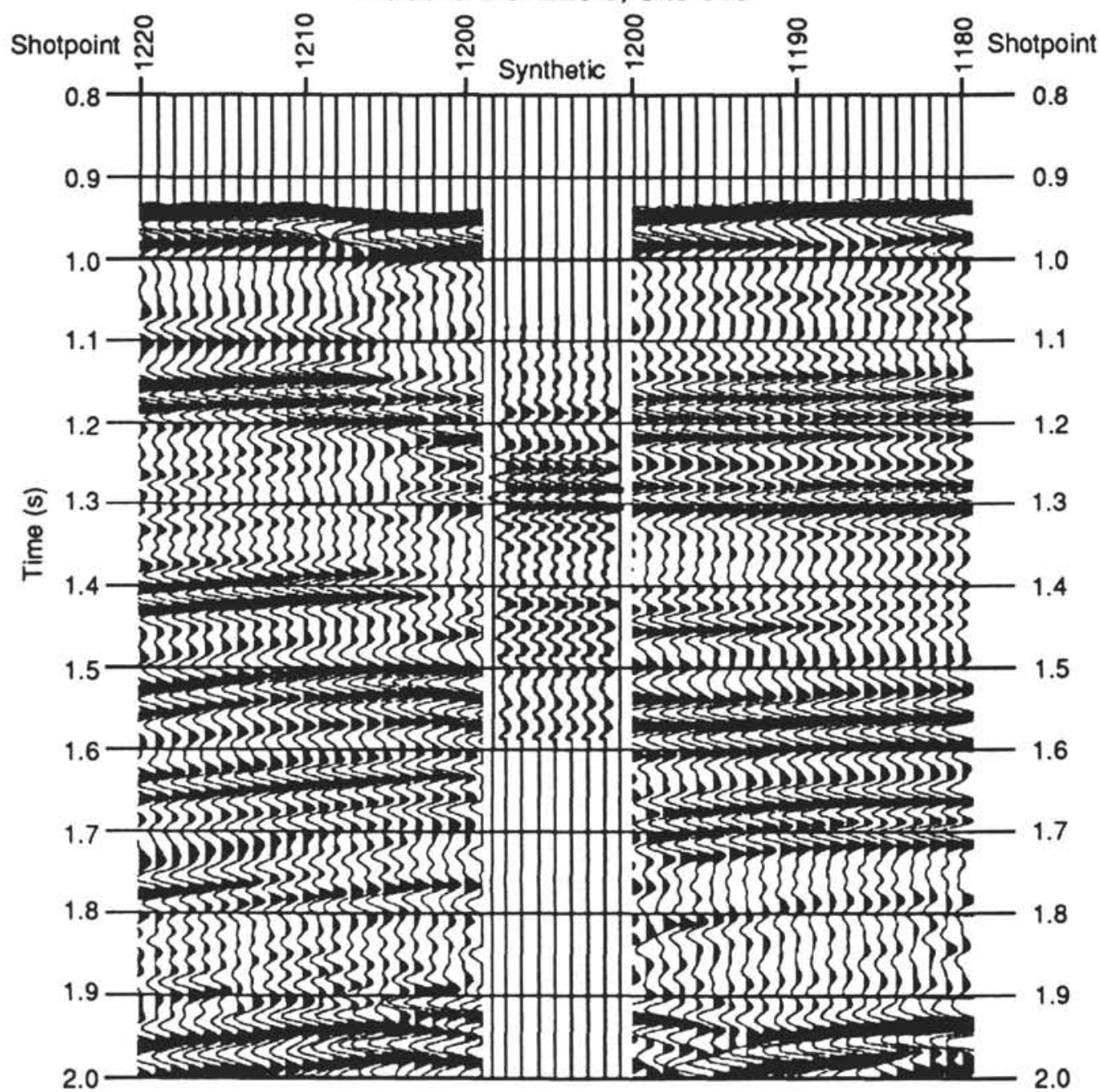

Figure 23 (continued). 
A SW

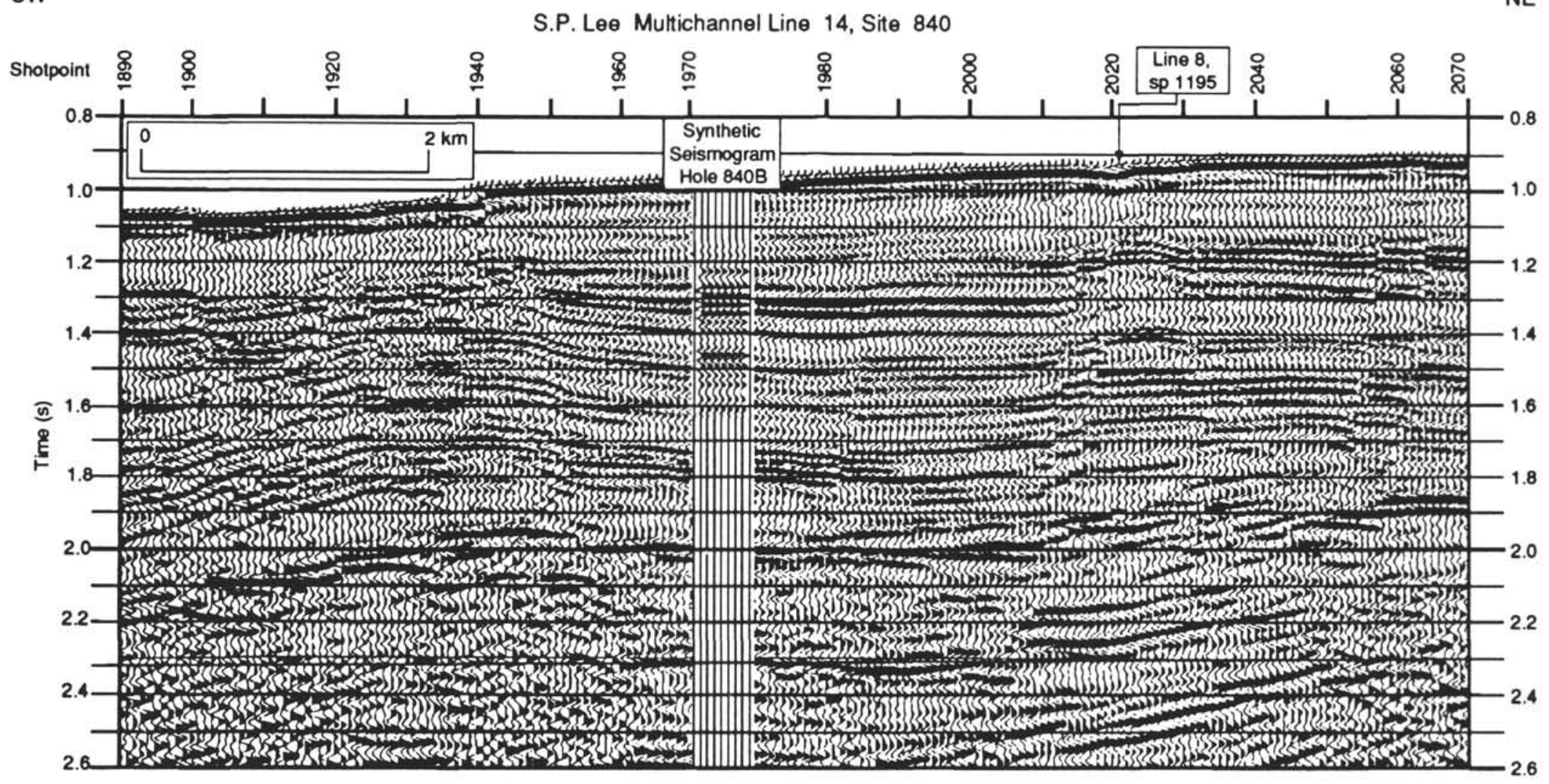

Figure 24. Synthetic seismogram for Hole 840B spliced into migrated S.P. Lee seismic line 14, shotpoints 1890-2070 (A), and migrated S.P. Lee seismic line 8, shotpoints $1100-1297$ (B). Line locations shown in Figure 21. 
B w

S.P. Lee Multichannel Line 8 , Site 840

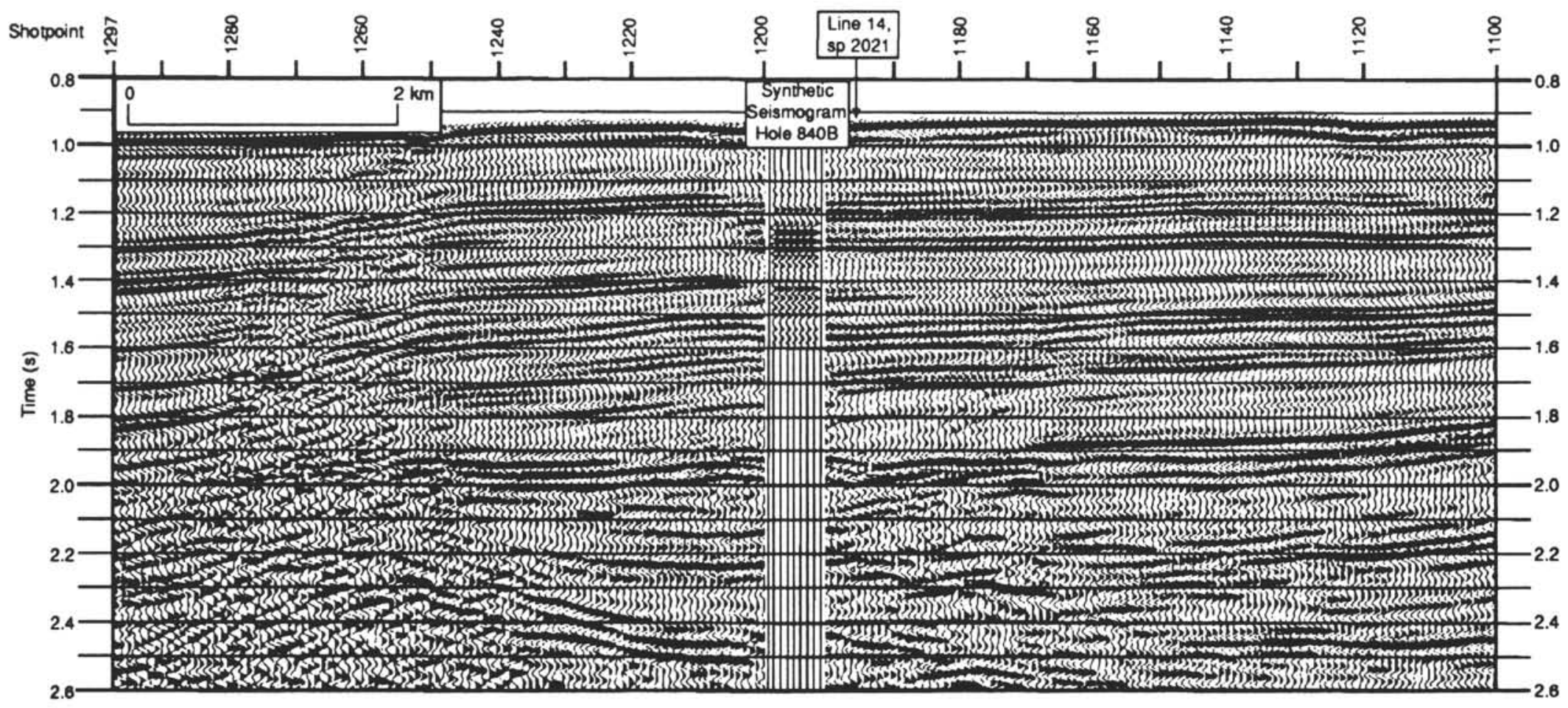

Figure 24 (continued). 


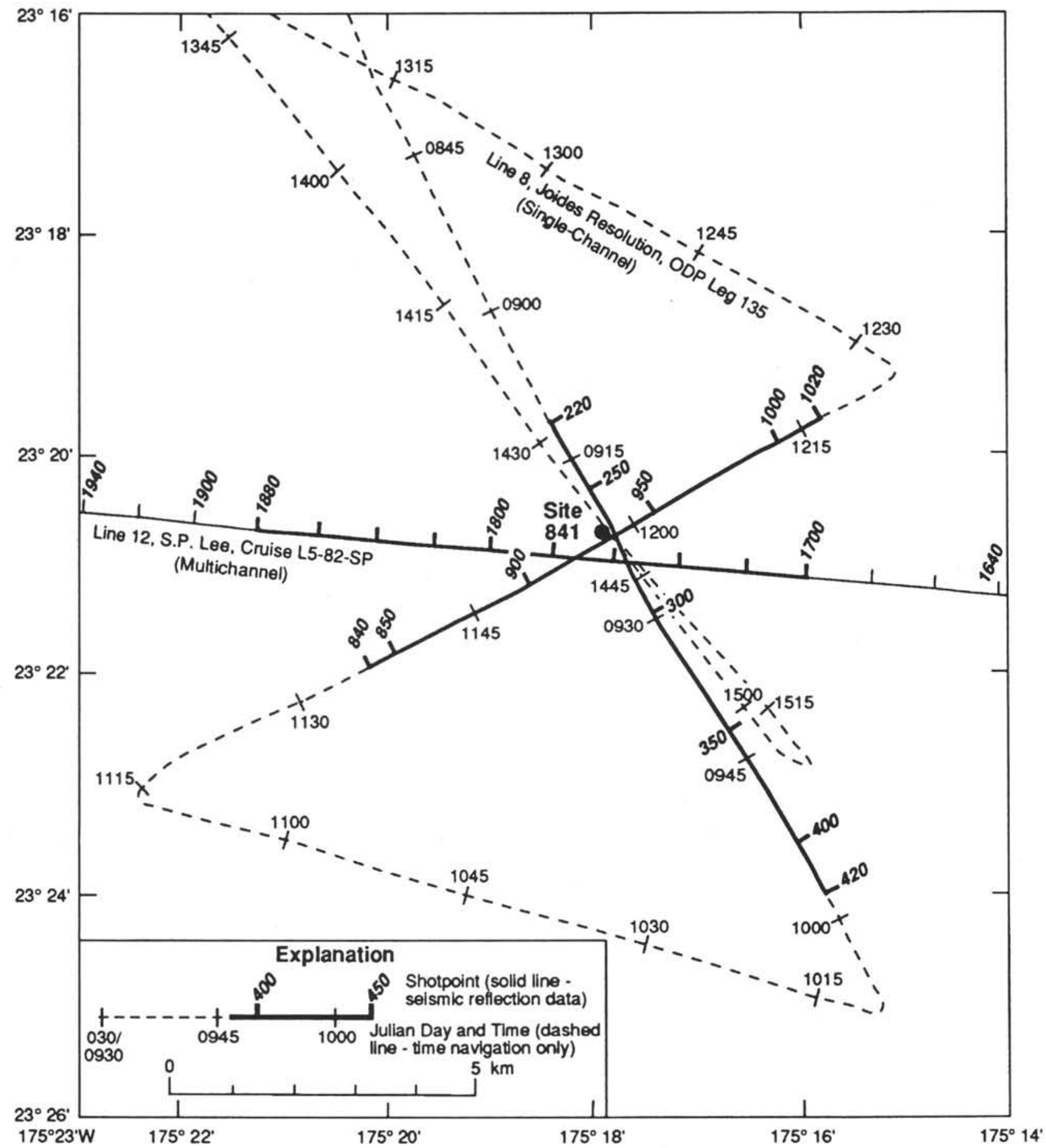

Figure 25. Location of S.P. Lee multichannel seismic line 12 and JOIDES Resolution single-channel seismic line 8 across Site 841. 


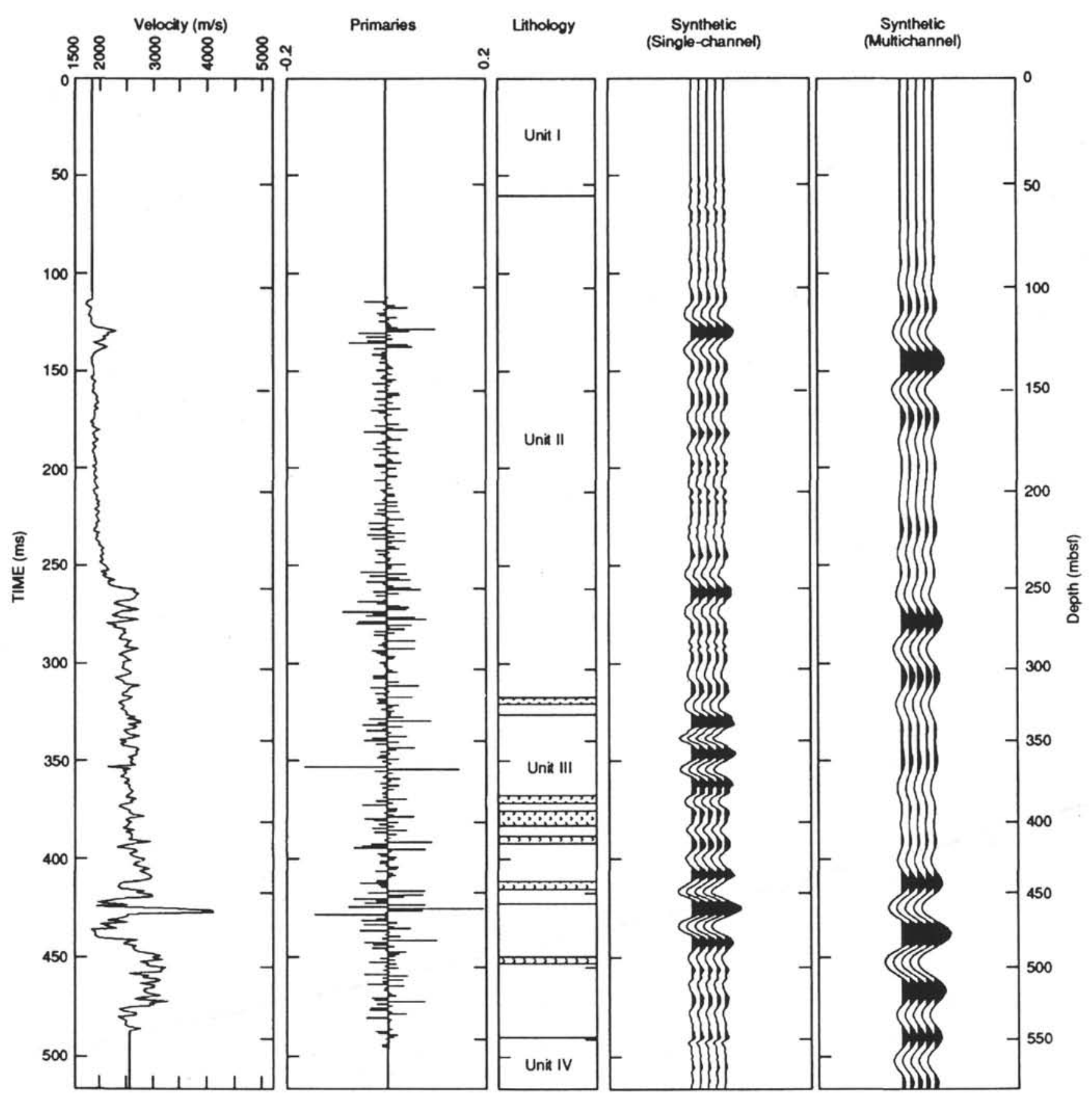

Figure 26. Plot of sonic velocity from logging data $(\mathrm{m} / \mathrm{s})$, plot of calculated reflection coefficients, simplified lithologic column, and synthetic seismograms for Hole 841C. Lithologic column is from Parson, Hawkins, Allan, et al. (1992, pp. 571-677). Two-way traveltime in ms annotated on left side of each column, and depth in mbsf annotated on right side. 
A W

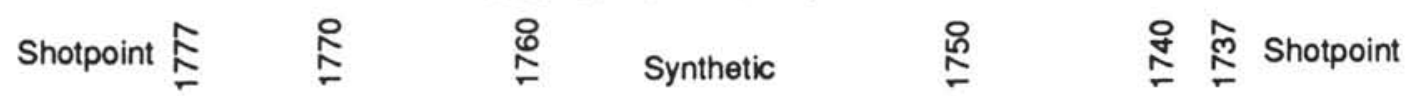

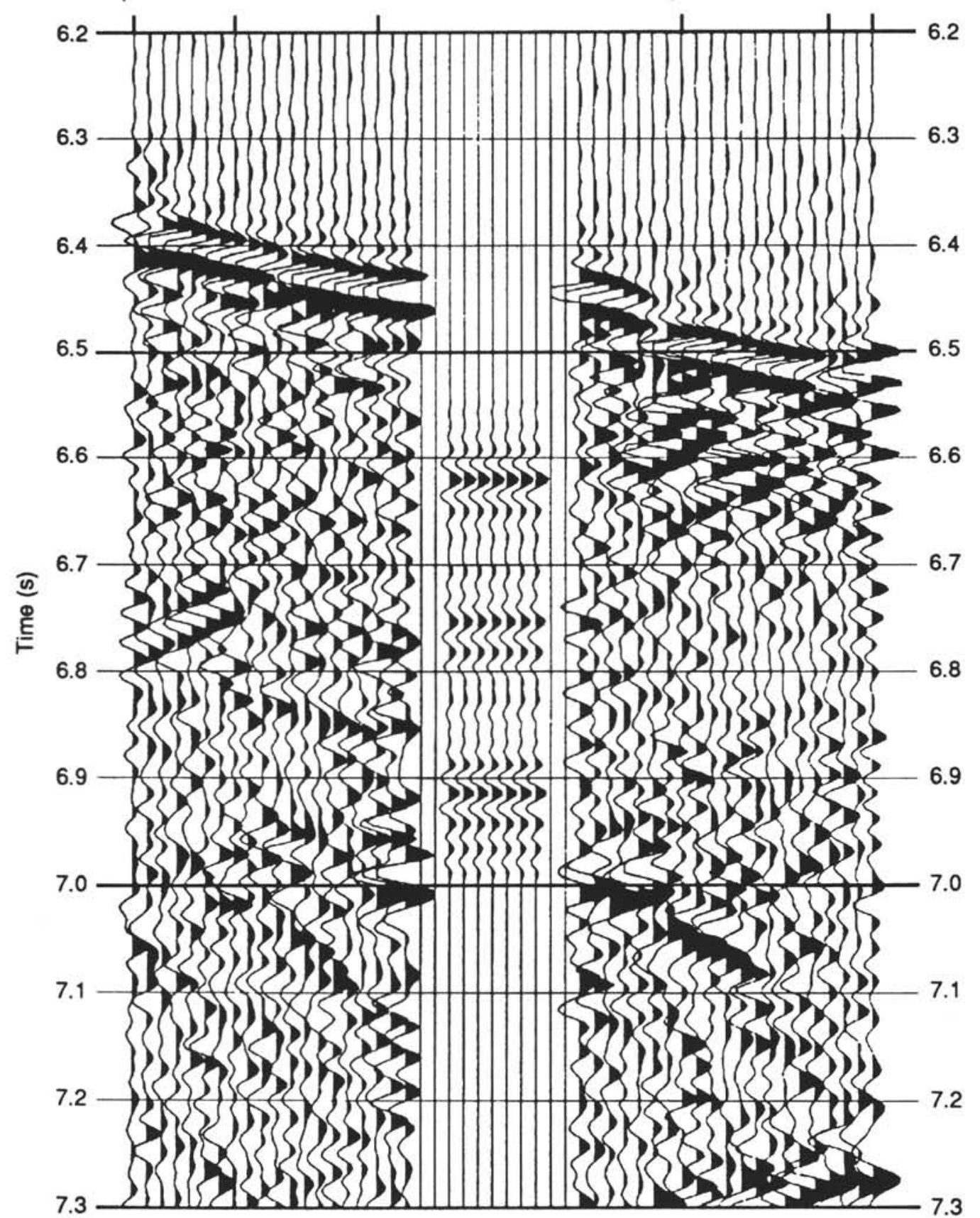

Figure 27. Synthetic seismogram for Hole $841 \mathrm{C}$ spliced into a 40-shotpoint segment of migrated S.P. Lee multichannel seismic reflection line 12 shot downslope (A), migrated JOIDES Resolution seismic line 8 trending downslope (B), and migrated JOIDES Resolution seismic line 8 shot parallel to the slope (C). Line location shown in Figure 25. 
B NW

Line 8, Downslope, Site 841

SE

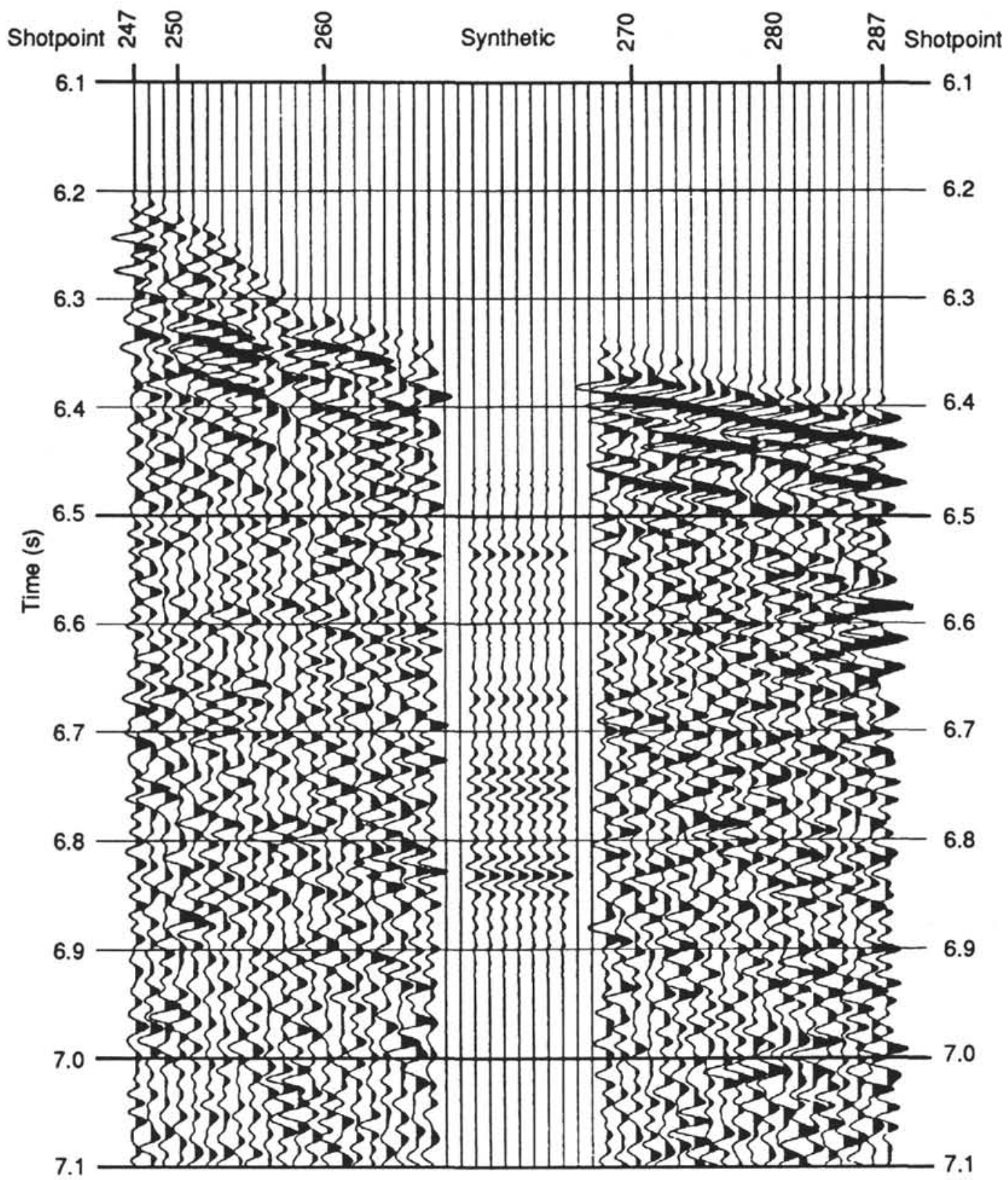

Figure 27 (continued). 
C SW

Line 8, Slope Parallel, Site 841

NE

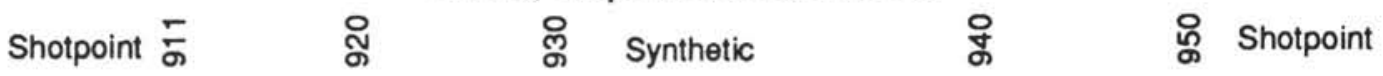

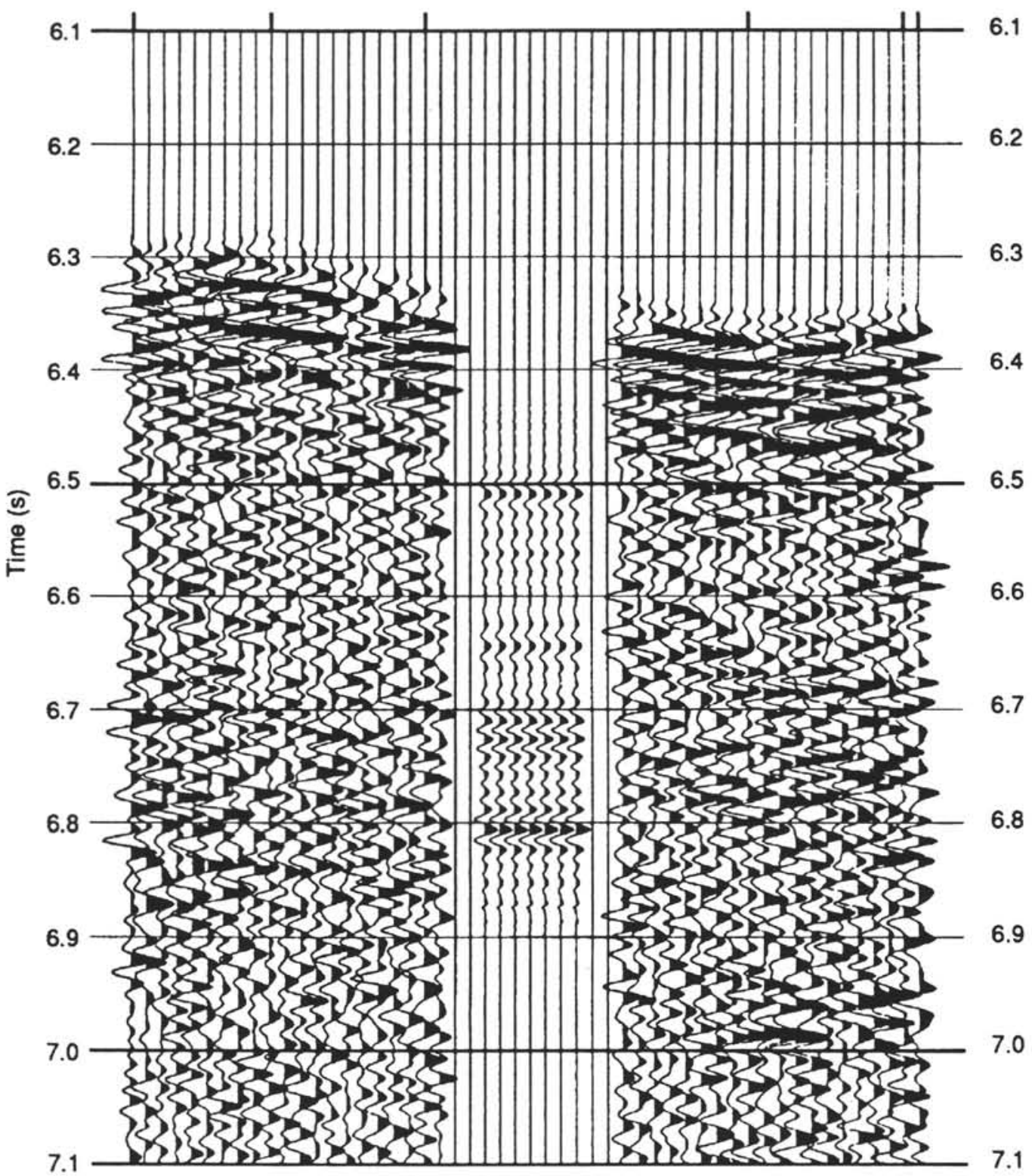

Figure 27 (continued). 


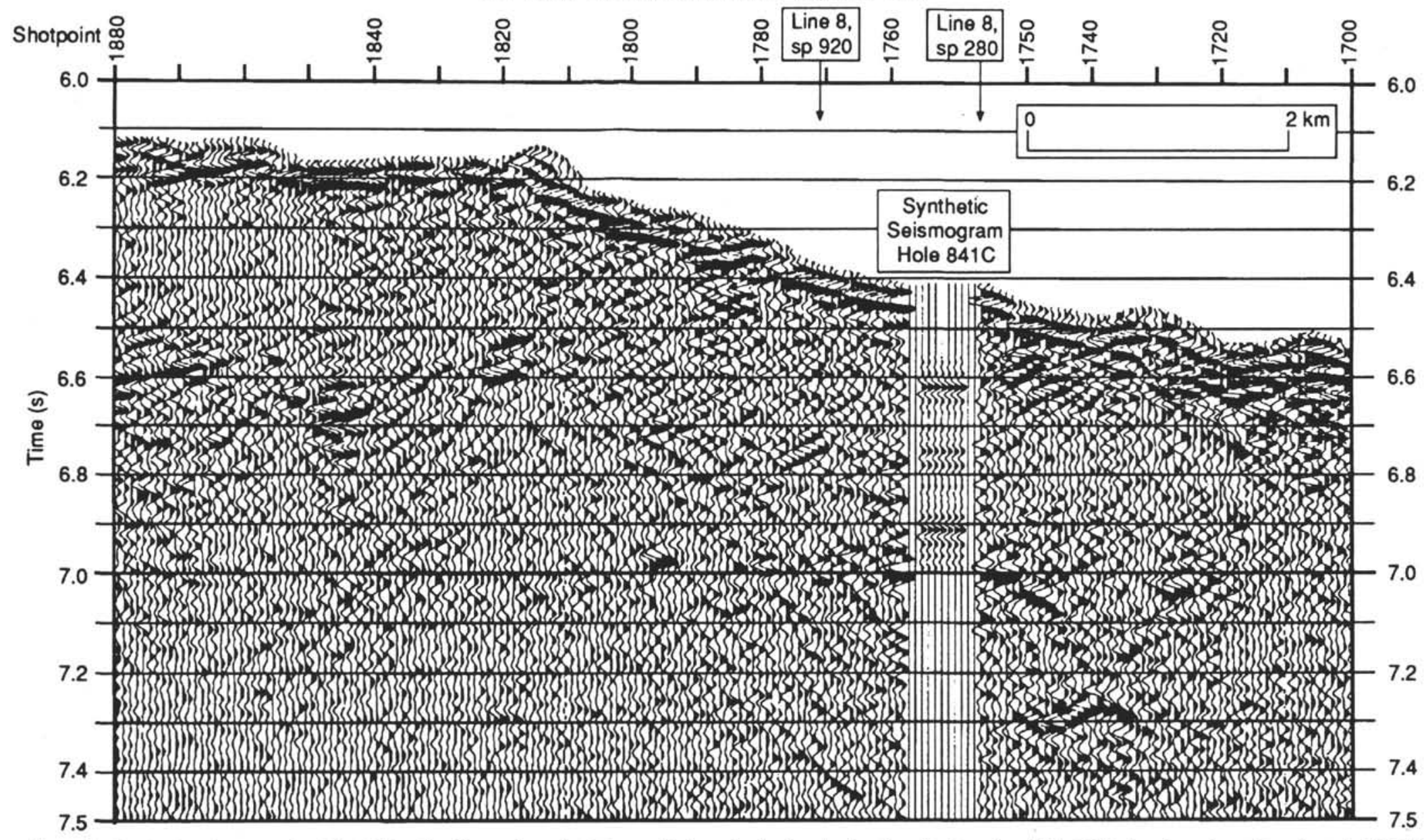


B NW

JOIDES Resolution Line 8, Downslope, Site 841

SE

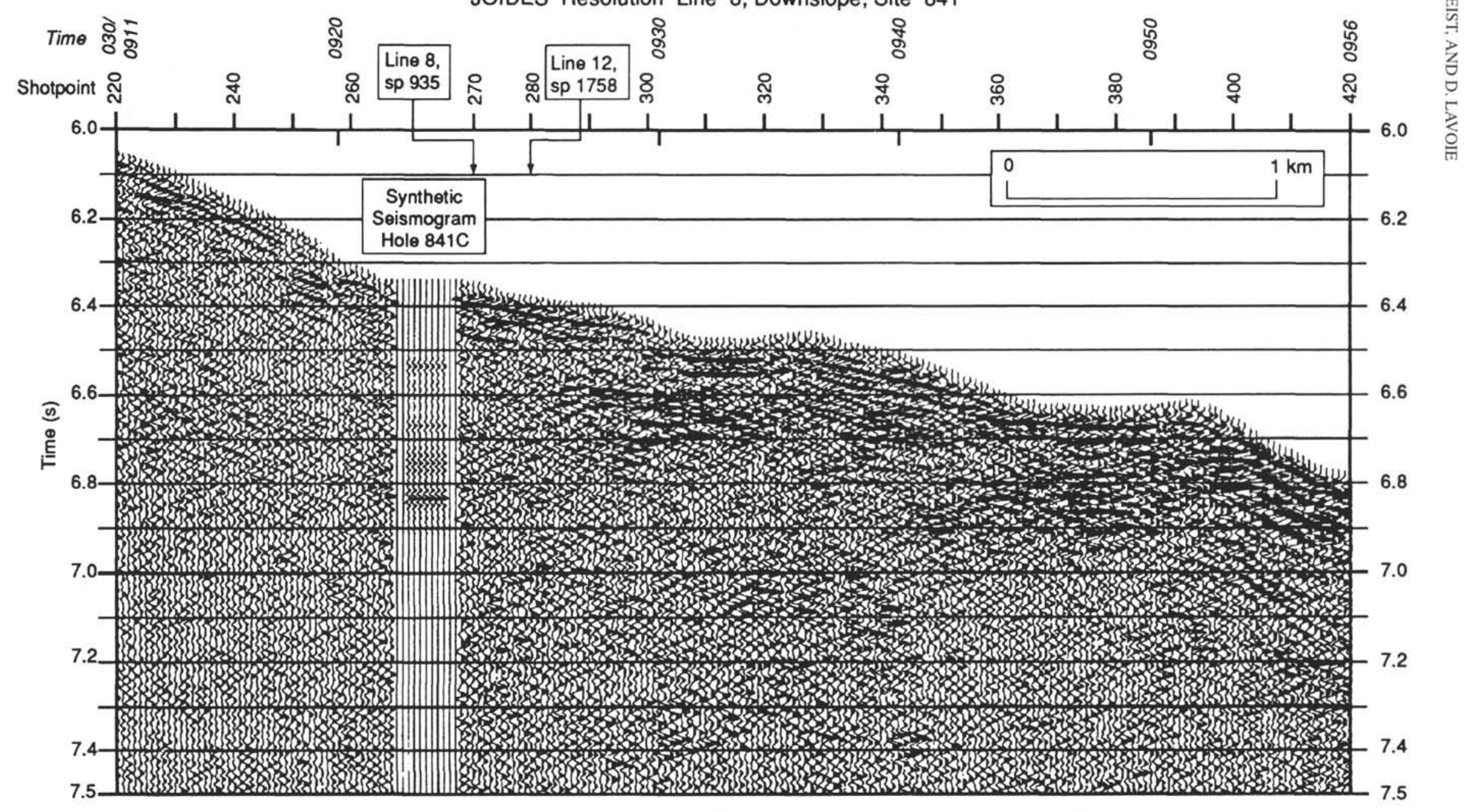

Figure 28 (continued). 
C SW

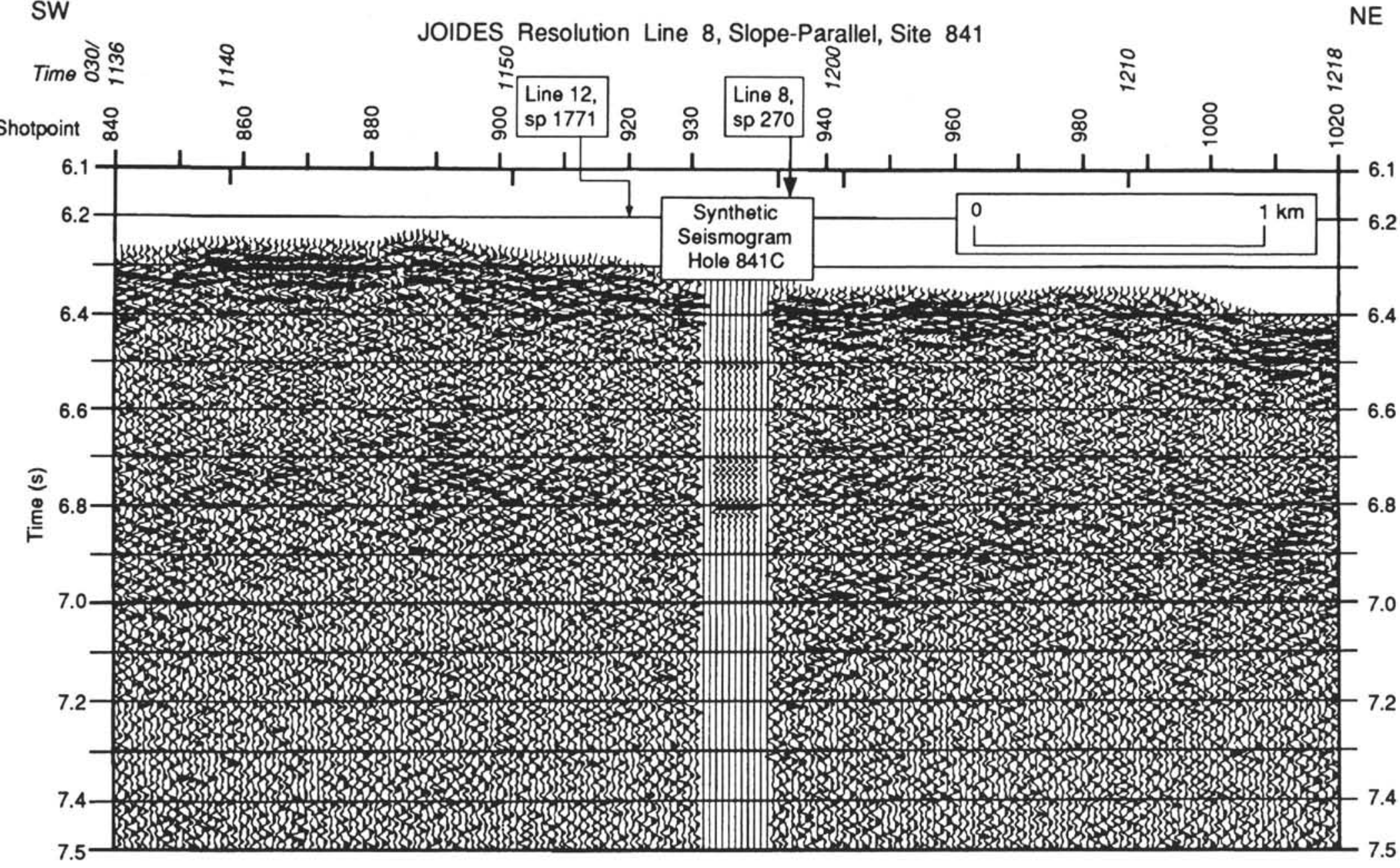

Figure 28 (continued). 